\title{
Diagnosis of the Maturity Level of Implementing Industry 4.0 Solutions in Selected Functional Areas of Management of Automotive Companies in Poland
}

\author{
Ewa Stawiarska, Danuta Szwajca, Mirosław Matusek (D) and Radosław Wolniak *(D)
}

check for

updates

Citation: Stawiarska, E.; Szwajca, D.; Matusek, M.; Wolniak, R. Diagnosis of the Maturity Level of

Implementing Industry 4.0 Solutions in Selected Functional Areas of Management of Automotive Companies in Poland. Sustainability 2021, 13, 4867. https://doi.org/ $10.3390 /$ su13094867

Academic Editor: Marc A. Rosen

Received: 10 February 2021

Accepted: 20 April 2021

Published: 26 April 2021

Publisher's Note: MDPI stays neutral with regard to jurisdictional claims in published maps and institutional affiliations.

Copyright: (c) 2021 by the authors. Licensee MDPI, Basel, Switzerland. This article is an open access article distributed under the terms and conditions of the Creative Commons Attribution (CC BY) license (https:/ / creativecommons.org/licenses/by/ $4.0 /)$.
Organization and Management Department, Silesian University of Technology, 41-800 Zabrze, Poland; ewa.stawiarska@polsl.pl (E.S.); danuta.szwajca@polsl.pl (D.S.); miroslaw.matusek@polsl.pl (M.M.)

* Correspondence: radoslaw.wolniak@polsl.pl

\begin{abstract}
The automotive sector is one of the key branches of the global economy. The automotive industry is also a very important sector of the Polish economy, as it generates over $8 \%$ of GDP and accounts for over $20 \%$ of the annual export value. Industry 4.0 and the effective use of modern technologies give a chance for its further dynamic development. The implementation of Industry 4.0 solutions in the business processes of automotive companies should not only take place in the area of production or logistics, as it is usually indicated, but also in their other functional areas, such as quality management, human resources management, and innovation management. The purpose of the article is to diagnose the level of maturity in the implementation of Industry 4.0 solutions in selected management areas of automotive companies operating in Poland. Using a maturity assessment tool, the authors assessed the level of maturity in six selected functional areas of an enterprise, such as production and logistics management, quality management, human resources management, social and environmental responsibility, and product innovation management. The authors also formulated conclusions and recommendations concerning actions that should be taken by automotive companies in order to achieve higher maturity levels in the implementation of Industry 4.0 solutions.
\end{abstract}

Keywords: Industry 4.0; automotive; manufacturing; logistics; quality management; human resources management; corporate social responsibility; innovation management

\section{Introduction}

The world's largest automotive companies are advanced in implementing key technologies for Industry 4.0, such as automation and robotics, which they also expect from their supply chain partners. Despite a higher saturation of automation and robotics in production processes than companies in other industries, these companies also face the challenges of digital transformation in other management areas as well. Indeed, digital transformation refers to the economic and social impact of the digitalization of organizations.

The current fourth industrial revolution, referred to as Industry 4.0, can be understood as the end-to-end digitization and interconnection of business processes, starting with the development of a new product offering, through customer orders, the production process, the delivery of the product to the point of consumption ending with all after-sales and accompanying services for the aforementioned processes [1]. As a result, it is expected that this will create largely self-organizing value creation networks that will be able to provide companies with greater flexibility, increased competitiveness, and the acquisition of sustainable adaptability to the changing business environment [2,3].

Piccarozzi et al. [3] conducted a review of research on Industry 4.0 in management and quality sciences. On this basis, they identified several emerging research areas. Among these, the authors mention research on the impact of Industry 4.0 on (1) production and quality management methods in production; (2) creation of new or change of existing 
business models; (3) strategies of companies; (4) results achieved by companies in the dimensions of value creation, individualization of the product offering, sustainable development, competitiveness, efficiency, learning processes; (5) human resources management; (6) development of small and medium-sized enterprises; (7) supply chains; (8) sustainable development; (9) information systems; and (10) innovation (including social innovation). The listed areas are given in descending order of the number of publications in which a given topic is addressed.

It is important to state that these areas are still at an early stage of recognition. Most of the research conducted is more conceptual than empirical [3]. The overwhelming number of publications present only the results of research on the awareness among employees and managers of the need to implement development strategies, new business models, or the use of Industry 4.0 tools and technologies. Moreover, among the empirical studies, those conducted on a very small sample (a few companies) dominate. The awareness of the managers as to the necessary changes or a created vision is important, but it is "only" the first step in the digital transformation of a company. The next step is to develop a roadmap for this transformation, which will depend on the current level of maturity of the already implemented or not yet implemented elements that make up Industry 4.0. However, as the results of research show $[4,5]$, managers have a problem with defining their current state of development in relation to the vision of Industry 4.0, and consequently, they cannot identify specific areas of activities, programs, and projects. New methods and tools are needed to provide guidance and support in aligning business strategies and operations with the Industry 4.0 concept [5].

Maturity models are commonly used as a tool to conceptualize and measure the maturity of an organization or process with respect to a specific target state [6]. Generally, the term 'maturity' refers to "a state of reaching full development, a state of readiness for specific tasks" and suggests some progress in the development of a system. Accordingly, maturing systems (e.g., biological, technical, organizational) increase their capabilities over time to reach the desired state in the future.

Although there have already been many proposals for models of maturity of implementation of solutions that make up Industry 4.0, as indicated in the literature [6], they differ primarily in scope; i.e., some of the proposed tools are used to measure only selected functional areas (most often manufacturing and logistics), some take into account a loosely selected set of elements that make up the architecture of the organisation (strategy, human resources, business processes), some focus on the assessment of implemented digital technology solutions.

The purpose of the article is to assess the level of maturity of the implementation of Industry 4.0 solutions in six functional areas of management, i.e., management of production and logistics, quality, human resources, social and environmental responsibility, and product innovation of automotive companies in Poland.

The tool developed for the purpose of this study to assess maturity in the implementation of Industry 4.0 solutions was based on the value chain concept. It was the basis for determining the scope of company maturity assessment (i.e., activities in the nomenclature of value chain components) and dimensions (i.e., statements characterizing a given level of maturity assessment). Ultimately, the scope of the maturity assessment included production, quality management, logistics, human resources management, innovation management, and corporate social responsibility.

Due to the small number of available empirical research results and the still low level of implementation of Industry 4.0 solutions in Polish enterprises, the present research has an exploratory character, in which the authors wanted to recognize the phenomenon of digital transformation among Polish enterprises of the automotive industry. According to the authors, the research will be a starting material for further research in this area.

In order to answer the research questions, a maturity model was used. The data were collected through questionnaire surveys, and their analysis was carried out using 
descriptive statistics. The research was conducted on a sample of 50 employees/engineers from 50 automotive companies located in Poland.

The novelty of this research is firstly the development of a tool to measure the maturity of the implementation of Industry 4.0 solutions based on Porter's concept of the value chain. This allowed including in the assessment not only the production area but also logistics, quality, human resources, social and environmental responsibility, and product innovation. Moreover, to the best of the authors' knowledge, the assessment of maturity among enterprises from the automotive industry located in Poland is the first such research conducted on a research sample larger than a few enterprises.

The remaining part of the article is divided into the following sections. Section 2 presents symptoms of implementing Industry 4.0 solutions in management. Section 3 presents the research questions, the research methodology, the data collection method, and the characteristics of the research sample. The results of the conducted research are included in Section 4. Based on the results obtained, Section 5 presents a discussion regarding the research questions posed. Finally, Section 6 concludes this study by presenting the contributions to the study, the limitations of the research carried out, and indications of directions for future research. Figure 1 presents the research procedure.

\begin{tabular}{|c|c|c|c|c|c|}
\hline \multicolumn{6}{|c|}{$\begin{array}{l}\text { Assessment of the maturity of implementation of Industry } 4.0 \text { solutions } \\
\text { in enterprises from the automotive industry }\end{array}$} \\
\hline \multicolumn{6}{|c|}{$\begin{array}{l}\text { Literature review on the implementation of Industry } 4.0 \text { solutions } \\
\text { (see Section 2) }\end{array}$} \\
\hline $\begin{array}{lr}\begin{array}{lr}\text { Symptoms } \\
\text { implementing }\end{array} & \\
\text { Industry } & 4.0 \\
\text { solutions } & \text { in } \\
\text { production } & \\
& \\
& \\
\text { (see Section } & 2.1 \text { ) }\end{array}$ & $\begin{array}{l}\text { Symptoms of } \\
\text { implementing } \\
\text { Industry } \\
\text { solutions in } \\
\text { company logistics } \\
\text { and the supply } \\
\text { chain } \\
\text { (see Section } 2.2 \text { ) }\end{array}$ & $\begin{array}{lr}\text { Symptoms of } \\
\text { implementing } \\
\text { Industry } \\
\text { solutions } \\
\text { quality } \\
\text { management }\end{array}$ & $\begin{array}{l}\text { Symptoms of } \\
\text { implementing } \\
\text { Industry } \\
\text { solutions in } \\
\text { human resources } \\
\text { management } \\
\text { (see Section 2.4) }\end{array}$ & $\begin{array}{l}\text { Symptoms of } \\
\text { implementing } \\
\text { Industry } 4.0 \text { in } \\
\text { socially } \\
\text { responsible } \\
\text { corporations } \\
\text { (see Section } 2.5 \text { ) }\end{array}$ & $\begin{array}{l}\text { Implementation } \\
\text { of Industry } 4.0 \\
\text { solutions in } \\
\text { innovation } \\
\text { management } \\
\text { (see Section 2.6) }\end{array}$ \\
\hline \multicolumn{6}{|c|}{$\begin{array}{l}\text { Literature review on the maturity assessment of the implementation of Industry } 4.0 \text { solutions } \\
\text { (see Section } 3.2 \text { research methodology) }\end{array}$} \\
\hline $\begin{array}{l}\text { A tool to assess } \\
\text { the maturity of the } \\
\text { implementation } \\
\text { of Industry } 4.0 \\
\text { production }\end{array}$ & $\begin{array}{l}\text { A tool to assess } \\
\text { the maturity of } \\
\text { implementing } \\
\text { Industry } 4.0 \\
\text { solutions in } \\
\text { company logistics } \\
\text { and the supply } \\
\text { chain } \\
\text { (Appendix A Table } \\
\text { A2) }\end{array}$ & $\begin{array}{l}\text { A tool to assess } \\
\text { the maturity of } \\
\text { implementing } \\
\text { Industry } \\
\text { solutions in } \\
\text { quality } \\
\text { management } \\
\text { (Appendix A Table } \\
\text { A3) }\end{array}$ & $\begin{array}{l}\text { A tool to assess } \\
\text { the maturity of } \\
\text { implementing } \\
\text { Industry } 4.0 \\
\text { solutions in } \\
\text { human resources } \\
\text { management } \\
\text { (Appendix A Table } \\
\text { A4) }\end{array}$ & $\begin{array}{l}\text { A tool to assess } \\
\text { maturity of } \\
\text { Industry } 4.0 \\
\text { implementation } \\
\text { in CSR } \\
\text { management } \\
\text { (Appendix A Table } \\
\text { A5) }\end{array}$ & $\begin{array}{l}\text { A tool to assess } \\
\text { the maturity of } \\
\text { Industry } 4.0 \\
\text { solutions in } \\
\text { innovation } \\
\text { management }\end{array}$ \\
\hline \multicolumn{6}{|c|}{$\begin{array}{l}\text { Research results and conclusions } \\
\qquad \text { (see Sections } 4 \text { and } 5 \text { ) }\end{array}$} \\
\hline
\end{tabular}

Figure 1. Research course. Source: own elaboration.

\section{Literature Review}

Original Equipment Manufacturers (OEMs) and their suppliers are facing complex challenges today. The need to implement disruptive innovations in production processes and logistics (so-called advanced manufacturing and logistics) and materials (so-called advanced materials) is identified as two further challenges facing automotive manufacturers and suppliers today (e.g., $[7,8]$ ). This will require vendors and their OEM customers to implement Industry 4.0 solutions. The symptoms of implementing Industry 4.0 solutions 
in selected functional areas of the enterprise have been tracked by reviewing the literature (in the following subsections).

\subsection{Symptoms of Implementing Industry 4.0 Solutions in Production}

With the rapid technological progress observed, many new concepts for the transformation of their production systems are emerging before manufacturers. One of them is "Industry 4.0" [9-11]. However, as the literature points out [6], the conditions for achieving full maturity of Industry 4.0 in manufacturing are still not yet well defined. The roadmap for the development and adaptation of the new technologies that make up Industry 4.0 is not as clear to managers as it is among researchers [12]. The difficulty is already the very definition of the term Industry 4.0, which is not clearly understood in the literature. Meanwhile, the dimensions of maturity and the criteria for assessing the maturity of Industry 4.0 depend on the perspective adopted by the researcher $[13,14]$ and primarily the understanding of the dimensions of Industry 4.0. [6].

For the purpose of building a tool to assess the maturity of implemented Industry 4.0 solutions in the areas of production and logistics subsystems, it was assumed, following the proposal presented by Boston Consulting Group [15], that Industry 4.0 is a set of nine technologies (also called Industry 4.0 pillars). These include Big Data and Big Data Analytics, Augmented Reality, 3D Printing, Cloud Computing, Cyber Security, Autonomous Robots, Simulation, Horizontal/Vertical Software Integration, and Internet of Things (IoT). Some authors (e.g., [5,7]) add to this list also cyber-physical systems (CPS), and digital twins (DTs). They identify these as those that are taking a central position in new-generation intelligent manufacturing — that is, smart manufacturing. Their adoption by manufacturing companies should be understood as comprehensive digitalization in order to link production and logistics processes covering the entire product life cycle, i.e., starting from product and service design, customer order handling, product manufacturing, delivery to the point of consumption up to after-sales service, including reverse logistics activities.

The changes resulting from their implementation require a long development period and should encompass production processes and systems, the change of the business model, product offerings, and customers [16]. In the manufacturing area, the maturity of Industry 4.0 should be understood as full integration, in which not only all production equipment (sensors, machines, robots, conveyors, etc.) are connected and automatically exchange data and information with each other but will also become self-aware and intelligent enough to predict events, control production processes, and manage the entire manufacturing system [16,17]. In addition, many of the processes that make up manufacturing, such as product design, production planning, and manufacturing, are closely interconnected, which in effect means that these processes are not only controlled by the decentralized system but also controlled interdependently [12].

\subsection{Symptoms of Implementing Industry 4.0 Solutions in the Company's Logistics and Its Supply Chain}

Industry 4.0 based on disruptive innovation includes not only manufacturing systems but also logistics or entire supply chains. According to the Council of Supply Chain Management Professionals (CSCMP), logistics is " ... that part of supply chain management that plans, implements, and controls the efficient, effective forward, and reverse flow and storage of goods, services, and related information between the point of origin and the point of consumption in order to meet customers' requirements" [18]. Then, the essence of the logistics process is the management of the flow of both materials and information. Moreover, logistics can be considered as a system that can be further divided into individual interdependent subsystems [19]. These individual subsystems are purchasing logistics, production logistics distribution logistics, and after-sales logistics. In addition to material and information flows, they form further areas that should be assessed for maturity in implementing Industry 4.0 solutions [19-21].

There is an enormous amount of data available in logistics processes and an opportunity to use information technologies that can significantly improve their efficiency and 
effectiveness. Studies (e.g., $[19,21])$ indicate that data analysis, communication, design, and optimization of logistics processes can be improved through their use in logistics. The digitalization of logistics processes leads to a 'logistics transformation' or to the creation of 'smart logistics solutions'. In this case, Industry 4.0 is to be seen as a new level of organization and control across the entire value chain during the product life cycle, taking into account increasingly individualized customer requirements. The basis is the availability of the required information in real time by connecting all instances involved in the value chain both within and between companies [19]. Hence, similar to production, logistics, both internal and external, must adapt to changing needs. In this case, the term "Logistics 4.0" (sometimes the phrase "4.0" is replaced by "smart" or "intelligent", e.g., "Intelligent Logistics"), which is increasingly used in practice and the literature, should rather be understood to refer to the combination of logistics activities with the innovations and applications offered by Industry 4.0. The "intelligence" of Logistics 4.0 should be read as a characteristic of such a logistics system, which has more flexibility than a traditional logistics system, an automatic ability to adapt to market changes, and individualised storage and transport needs of customers. In this case, if the term Logistics 4.0 means the specific application of Industry 4.0 solutions in the field of logistics, then in the case of automotive manufacturers/suppliers, it means their application in areas such as procurement logistics, internal (production) logistics, distribution logistics, and after-sales logistics [20].

The dimension of digitalization seems to be crucial here in assessing the maturity of logistics processes. Supply chain digitization can be defined as a set of ICT resources that an organization uses to interact with an enterprise network in order to move activities and physical objects into a digital space by integrating the physical world with the digital world for the purposes of (1) minimizing the resources used and improving the efficiency of operations, and (2) achieving full real-time visibility of the network, and such integration refers to the collaboration of all actors in the supply chain at all stages using advanced techniques and data management capabilities [22].

\subsection{Symptoms of Implementing Industry 4.0 Solutions to Quality Management Systems}

To implement Industry 4.0 solutions to the quality management area, we should base them on typical methods and tools used in the quality management area, but the Industry 4.0 and especially the digitalization of all organizational processes can add more value to the quality management area. The basis for the functioning of the automotive industry in the quality management area has become the adoption of standardization, as a tool for reducing production costs, allowing leading for mass production, etc. However, nowadays, there is also a need for so-called product customization and production tailored to specific customer needs. This is particularly important in the premium market. The customization of products in the automotive industry can be achieved due to digitalization and the possibility of using better and faster production planning in Industry 4.0. The use of customization of products is a manifestation of Industry 4.0 use in automotive organizations. Therefore, there is a need to maintain a balance between product standardization and adaptation to customer requirements, which is in line with the concept of Industry 4.0 [23-27].

The main objective of applying quality management standards in modern organizations included in the automotive industry is the continuous improvement of all processes in the company [28]. This applies both to the production process itself as well as to the entire area of the organization's activities. Preventive actions play an important role in this case as well as a reduction of variability and losses in the quality system, which leads to a reduction of manufacturing costs and increase of customer satisfaction. The effective system of analyzing and implementing improvements in production planning and production line is a proof of Industry 4.0 existence in the organization [29,30].

Since suppliers in the automotive industry often deliver products to customers from different countries, there was a need for them to implement several standards when they sold products to automotive companies from different countries [31,32]. In order to solve this problem and to harmonize the different assessment and certification system 
in the automotive supply chain, in 1999, the International Automotive Task Force (IATF) undertook the task of unifying standards in the industry. In 1999, it first issued the technical specification International Organization for Standardization Technical Specification-ISO/TS 16949 [33,34].

The goal of the newly developed IATF 16949:2016 standard is to develop a quality management system in a way that ensures continuous improvement, focused on preventing errors and reducing variability and loss in the supply chain [35-40]. The standard in question defines the basic requirements for quality management systems in mass production and parts manufacturing. The standard is currently not recognized as an independent quality management standard, but it should be understood as a complement to the basic quality management system standard ISO 9001:2015. The standard should be used together with the mentioned standard [37,38].

The new IATF 16949:2016 standard is developed, similar to its earlier versions, according to the principle of process approach [36]. The assumption is that this approach makes good use of continuous improvement using the Plan-Do-Check-Act (PDCA) cycle. This cycle enables an organization to ensure that its processes are adequately resourced and managed and that opportunities for improvement are identified and addressed [35,41,42]. The use of IATF standards means careful description of all organization processes and links between organizations in the supply chain. The digitalization of IAFT 16949:2016 standard implementation is a very good manifestation of Industry 4.0 in automotive organizations. In addition, Industry 4.0 can be very useful in the process of implementation of many quality management methods, which need online data to use them.

Currently, more than 600 organizations in Poland have a certified quality management system in the automotive industry [43].

\subsection{Symptoms of Implementing Industry 4.0 Solutions in Human Resources Management}

The fourth industrial revolution, causing many changes in production processes and systems, also results in changes in the role of employees and requirements for their qualifications. Industry 4.0 solutions marginalize the role of people in manufacturing processes, which particularly refers to people with low skills [44-46]. The place of unskilled workers is increasingly being replaced by machines, robots, or IT systems that can work faster, more efficiently, more precisely, and above all cheaper. Experts predict that in the next several years, more and more intelligent machines and devices will appear, which will take over many functions that require thinking (e.g., supervising the course of processes, controlling compliance with regulations and procedures, creating schedules, monitoring the implementation of plans, etc.), which will lead to the elimination of many professions and specialties previously performed by humans [47-50]. This does not mean that the role of humans in the new digital reality will be less; on the contrary, humans with their creative and adaptive abilities will remain a decisive factor in the smart factory [51,52]. The obvious differences between highly skilled pilots and the autopilot probably do not need to be explained [53]. However, in the new conditions created by the implementation of Industry 4.0 solutions in the automotive industry (and beyond), employees with specific, high qualifications will be needed, which applies to both engineering and managerial staff. The maturity of the implementation of Industry 4.0 in the area of human resource management is manifested in the possession of appropriate competences by employees, both engineers and managers. The fact that employees of an automotive industry company have the competences of an engineer 4.0 and a manager 4.0 can be considered as symptoms of the maturity of the implementation of Industry 4.0 solutions in the area of human resource management. Engineer 4.0 competencies and manager 4.0 competencies have been indicated and described by many authors [15,54-56]. According to the suggestions of these authors, the professional competences of an engineer 4.0 should be more interdisciplinary and should include not only high-class technical skills (so-called hard) from many areas (i.e., mechanics, robotics, automation, electronics, IT, etc.), but also social skills and interpersonal (the so-called soft). In particular, an engineer 4.0 should have comprehensive IT and 
engineering knowledge, the ability to manage human-machine cooperation, the ability to manage devices distributed in the network, and the ability to manage change and manage a project team [57]. As the key competences of the manager 4.0, the following are mentioned: transfer of knowledge, detecting and supporting the development of inborn talents, building an organizational culture that fosters cooperation, social involvement, and the realization of ambitious tasks [58-64]. Both engineers 4.0 and managers 4.0 should be open and ready for constant changes and the necessity of continuous improvement of their skills $[65,66]$. According to Toffler [67], the illiterates of the 21st century will not be those who do not know Excel or cannot program but those who cannot learn new things and unlearn old ones.

New competences are a big challenge for enterprises not only from the automotive industry [68]. The results of research conducted in many countries on the preparation of employees to the requirements of Industry 4.0 indicate the occurrence of the so-called the competency gap [69-71]. In Germany, a country considered to be the initiator of Industry 4.0 , most of the surveyed companies assessed the competences of their employees in this area as "quite weak" [72]. The main barriers to implementing technology 4.0 are low employee competences, fears of losing a job, and insufficient support [73-75].

\subsection{Symptoms of Implementing Industry 4.0 in Socially Responsible Corporations}

The concept of corporate social responsibility is a very broad and multidisciplinary concept. The framework for the concept was published in 2010 in the ISO 26000 Guidance on social responsibility. The standard, developed by the International Organisation for Standardisation (ISO), defines Corporate Social Responsibility (CSR). Implementation of Industry 4.0 solutions aimed at increasing the social and environmental responsibility of enterprises has been addressed by the World Economic Forum (WEF). The WEF together with the McKinsey consulting company recognized trends, indicating the main development paths for factories of the future. Directions for the development of 4.0 technologies and key challenges for enterprises are discussed in the WEF white paper "Driving the Sustainability of Production Systems with Fourth Industrial Revolution Innovation" [76]. The white paper continues to serve as a guide to optimizing the benefits of the fourth industrial revolution in manufacturing, helping companies identify ways to transform their production systems, achieve sustainable growth, and contribute to the UN's Sustainable Development Goals. The paper encouraged regulators to support industry investment in autonomous robots and robotic systems, increasing environmental sustainability.

Researchers have conducted a number of studies showing that technologies associated with Industry 4.0 have unique potential to support environmentally friendly manufacturing $[77,78]$. Industry 4.0 technologies can reduce energy and resource consumption through sensing and data transfer, analyze production and supply chain processes [79], and lead to less waste and $\mathrm{CO} 2$ emissions through carbon footprint analyses [80,81]. Actions taken by the company to achieve higher levels of maturity in implementing Industry 4.0 solutions in the area of CSR are mentioned by Miśkiewicz [82] and Habek [83].

Researchers have conducted a number of studies showing that technologies associated with Industry 4.0 have unique potential to support environmentally friendly manufacturing [82,84]. Industry 4.0 technologies can reduce energy and resource consumption through sensing and data transfer, analyze production and supply chain processes [67], and lead to less waste. In the dimension of social sustainability, smart and autonomous production lines can support worker health and safety by taking over monotonous and repetitive tasks, resulting in higher worker satisfaction and motivation $[85,86]$. Some of the 4.0 solutions have focused on specific industrial problems related to sustainability, such as the circular economy [87]. A systematic review of Industry 4.0 technologies developed for sustainability is presented by $[88,89]$. Researchers also show that still, many manufacturing companies do not identify and evaluate the environmental value of their technologies $[15,90,91]$. 
Researchers have prepared a set of Key Performance Indicators (KPIs) [92,93] to assess the environmental impact of Industry 4.0 technologies. Industry 4.0 technologies are part of a complex architecture that integrates production and information technologies [94]. There are known ways to assess the impact of implementing 4.0 technologies on outcomes (economic and environmental and social) in companies from different industries (including automotive) [95].

The correlation between Industry 4.0 technologies and sustainability was sought by $[96,97]$. The researchers weighed that it is necessary to evaluate the usefulness of technologies for the sustainability of specific industries, because their future will depend on today's choices. They also believed that it was necessary to create procedures for implementing 4.0 technologies and measuring pro-social and pro-environmental changes. According to [98], it is necessary to develop methodologies and procedures for carrying out digital transformation in companies from a CSR perspective. The authors proposed a conceptual model of the transformation procedure.

Various studies indicate that aligning CSR practices with a company's digital business operations improves its financial performance [98,99]. Companies adopting 4.0 technologies are introducing a sustainability index to assess maturity digitalization [100].

Sustainable Production Assessment and Management Tools were designed [101,102]. Some of the proposed assessment tools have been implemented into simulation software (automotive industry); e.g., ARENA and SIMIO have been described [103].

A key challenge for the automotive industry today is to implement Industry 4.0 solutions with a common (supply chain-wide CSR policy). Vehicle manufacturers-supply chain integrators implement Green Supply Chain Management (GSCM), European Supply Chain Management (ESCM), and Electronic Supply Chain Management (e-SCM) concepts. Industry 4.0 solutions dedicated to green supply chains have been described [104-108]. The level of maturity in implementing Industry 4.0 solutions and, at the same time, the intensity of CSR activities was dealt with [109].

\subsection{Symptoms of Implementing Industry 4.0 Solutions in Innovation Management}

Innovation management can be defined as the systematic planning, organizing, implementing, and controlling of activities carried out to develop and introduce new products and related processes [110-112]. Where product innovation requires technical and technological changes, innovative manufacturing processes are developed (using 4.0 technologies). Actions taken by the company to achieve higher levels of maturity in implementing Industry 4.0 solutions in the area of innovation are mentioned by Brzóska [113].

Managing the innovation process for the need for new product development means [114] idea generation and opportunity recognition, analysis, evaluation, and selection, and product concept development. Innovation process management can also be complemented by the technologies of Industry 4.0. The standards for innovation management are structured in the European standard European Standardization of Innovation Management CEN TS 16555 Innovation Management. It should be noted that the main feature of the new CEN TS 16555 standard, which distinguishes it from the previous edition, is to promote a process approach to management innovations and to stimulate continuous improvement through the implementation of Industry 4.0 solutions. Automotive industry is currently working on the link between IATF 16949:2016 and CEN TS 16555. Based on the CEN TS 16555 standard, the research tool used in this work was prepared (Appendix A).

Poznanska and Kraj [115] deal with the organization of Research and Development (R\&D) work in multinational corporations, networks, and supply chains. Stawiarska [116] pays attention to the possibility of reducing $R \& D$ costs by implementing solutions 4.0 . The efficiency of innovation activities is addressed by $[117,118]$. They consider that efficiency of innovation can be enhanced by cooperation in the Open Innovation model. However, the implementation of the new paradigm seems to be difficult in medium-high technology industries (such as automotive) due to the existing innovation culture [119]. Without the help of a network/supply chain integrator to support innovation activities, schedule R\&D, 
engage suppliers and customers early in innovation development, and integrate innovation processes using 4.0 solutions, it will be difficult to overcome the barriers of working together on new products. Some technologies classified as Industry 4.0 solutions, such as cloud computing, blockchain, and artificial intelligence, will overcome the limitations of open innovation management [120]. Selected automotive corporations are spearheading the implementation of 4.0 technologies in the management of innovation emerging from the open model (e.g., Toyota, Volkswagen) [121] improving the innovation performance of all links in the supply chain [116].

Few companies have a clearly articulated product innovation strategy [122]. They also do not have operationalized innovation management systems [116]. Few large companies have a formalized and digitalized innovation development process [123].

The simultaneous process model is increasingly being adapted to innovation management systems, Due to the spread of Industry 4.0 solutions, the integration of supply chain links is strategic in this model [124]. Shared innovation processes will use IT management tools such as IoT, cloud computing, blockchain, and artificial intelligence [125,126].

For the creation and presentation of innovative solutions, the communication channel with the end user using Industry 4.0 solutions is important [127] Multidirectional knowledge transfer determines creativity in engineering design, technological product development, and per-product services. Overcoming barriers to developing innovation in an open model and managing risk in a networked collaborative environment requires data security [128-130].

A new initiative is also to support the development of product innovations by helping to integrate potential cooperators in the implementation of Industry 4.0 solutions. Such assistance is provided by cluster animators [131]. Innovative companies (about 60 wellknown multinationals: Toyota, Brembo, Motherson Sumi System, MRF, Plastic Omnium, Gentherm, Kolto Manufacturing, Continental, Linamer, Valeo, among others) using artificial intelligence for supply chain modeling and the development of new products [132,133].

Summing up the literature analysis, we think that the problem of measuring the maturity of implementation of Industry 4.0 solutions in automotive industry is the new problem and that it is worth analyzing. There are many positions about the particular functional area and there were some researchers measuring the maturity of those areas-for example, quality management. However, only a small part of them were connected with Industry 4.0 implementation. We did not find any analysis conducted in the automotive industry measuring the implementation of Industry 4.0 maturity with the broad analysis of the particular functional areas of the companies.

\section{Methods}

3.1. Basics of Developing a Method for Diagnosing the Level of Maturity of Implementing Industry 4.0 Solutions in Selected Functional Areas of Enterprise Management

The results of the critical analysis of the recent literature have shown that there is a lack of methodical approach to the implementation of Industry 4.0 solutions. The authors deal with the implementation of 4.0 solutions only in selected areas of business management, assess the advancement of implementations, and recommend further steps. They rarely conduct their research in a specific industry. The identified research gap prompted us to look for answers to the detailed research questions posed, i.e.,:

1 What are the key challenges currently faced by companies operating in the automotive industry?

2 What is the level of maturity in the implementation of Industry 4.0 solutions in selected functional management areas of automotive enterprises operating in Poland?

3 Does the achieved level of maturity vary depending on the functional area, class of the manufactured automotive part, company size, or its place in the value chain?

4 What actions should be taken by a company to achieve higher maturity levels in implementing Industry 4.0 solutions? 


\subsection{Research Methodology}

A maturity model was used for the purpose of conducting this research. A maturity model is a conceptual model that consists of a sequence of discrete levels for a certain class of maturity factors (e.g., processes, structures, resources, or technologies) in one or more functional areas of an organization while representing the predicted, desired, or typical evolutionary path for these factors [134].

The concept of maturity was first proposed by Crosby, who defined it as a state of completeness, perfection, and readiness [135]. The maturity model has two functions, i.e., diagnostic and planning [136]. The first one allows evaluating the maturity factor (e.g., the level of implementation of particular practices, solutions, technologies, etc. is evaluated), and the second one allows indicating the way of development by determining the scope of practices necessary to implement in order to increase the maturity level of the factor. This method is widely used both in disciplines such as computer science and in management and quality sciences [137].

Hence, the development of a maturity model required, in the first stage of the research procedure, the definition of the desired development path of digital transformation of automotive manufacturing companies. To this end, a literature review was conducted to identify the challenges facing automotive companies in the context of the Industry 4.0 initiative and a review of existing maturity models for implementing the Industry 4.0 concept (presented in Table 1).

Table 1. Methods for assessing maturity in implementing Industry 4.0 solutions.

\begin{tabular}{|c|c|c|c|}
\hline $\begin{array}{l}\text { Model Name/ } \\
\text { Creator }\end{array}$ & $\begin{array}{c}\text { Stages of Engagement Maturity in } \\
\text { Industry } 4.0\end{array}$ & Dimensions to Be Assessed & $\begin{array}{c}\text { Comments on Assessment } \\
\text { Preparation }\end{array}$ \\
\hline $\begin{array}{l}\text { SIMMI } 4.0 \\
\text { Leyh et al. (2016) [138] }\end{array}$ & $\begin{array}{l}\text { Five stages: } \\
\text { 1. Basic level of digitization } \\
\text { 2.Cross-departmental digitization } \\
\text { 3. Horizontal and vertical digitisation } \\
\text { 4. Full digitization } \\
\text { 5. Optimised full digitization }\end{array}$ & $\begin{array}{l}\text { Four dimensions: } \\
\text { 1. Vertical integration } \\
\text { 2. Horizontal integration } \\
\text { 3. Digital product development } \\
\text { 4. Cross-technology criteria }\end{array}$ & $\begin{array}{l}\text { - Focus on the IT landscape } \\
\text { - General measures to enable } \\
\text { phased transitions }\end{array}$ \\
\hline $\begin{array}{l}\text { Schumacher et al. } \\
\text { (2016) [139] }\end{array}$ & $\begin{array}{l}\text { Likert scale ranging from } 1-“ \\
\text { undifferentiated" to } 5 \text {-"very } \\
\text { distinct". }\end{array}$ & $\begin{array}{l}\text { Nine dimensions of the } \\
\text { company detailed in nine areas: } \\
\text { 1. Strategy } \\
\text { 2. Leadership } \\
\text { 3. Customers } \\
\text { 4. Products } \\
\text { 5. Operations } \\
\text { 6 Culture } \\
\text { 7. People } \\
\text { 8. Management } \\
\text { 9. Technology }\end{array}$ & general questionnaire \\
\hline $\begin{array}{l}\text { ACATECH Schuh et al. } \\
\text { (2017) [140] }\end{array}$ & $\begin{array}{l}\text { Six stages: } \\
\text { 1. Computerization } \\
\text { 2. Connectivity } \\
\text { 3. Visibility } \\
\text { 4. Transparency } \\
\text { 5. Predictability } \\
\text { 6. Adaptability }\end{array}$ & $\begin{array}{l}\text { Four dimensions (capabilities of } \\
\text { Industry 4.0): } \\
\text { 1. Resources } \\
\text { 2. Information systems } \\
\text { 3. Organizational structure } \\
\text { 4 Culture }\end{array}$ & $\begin{array}{l}\text { - Opportunities are explored } \\
\text { for each area of the company } \\
\text { - Questionnaire combined } \\
\text { with visits }\end{array}$ \\
\hline
\end{tabular}


Table 1. Cont.

\begin{tabular}{|c|c|c|c|}
\hline $\begin{array}{l}\text { Model Name/ } \\
\text { Creator }\end{array}$ & $\begin{array}{c}\text { Stages of Engagement Maturity in } \\
\text { Industry } 4.0\end{array}$ & Dimensions to Be Assessed & $\begin{array}{c}\text { Comments on Assessment } \\
\text { Preparation }\end{array}$ \\
\hline Huber, (2016) [51], & $\begin{array}{l}\text { Level I-Basic level of digitization: } \\
\text { The company is not engaged in } \\
\text { Industry } 4.0 \text {. } \\
\text { Level II-Cross-Departmental } \\
\text { Digitalization: the company is } \\
\text { actively involved in the topic of } \\
\text { Industry 4.0. Digitalization is } \\
\text { implemented in various departments, } \\
\text { and the first requirements of Industry } \\
4.0 \text { are implemented in all areas of the } \\
\text { company. } \\
\text { Level III-Horizontal and Vertical } \\
\text { Digitalization. The requirements of } \\
\text { Industry } 4.0 \text { have been implemented } \\
\text { in the company, and the information } \\
\text { flow has been automated. } \\
\text { Level IV-Full Digitization. The } \\
\text { company is fully digitized. } \\
\text { Digitalization extends beyond } \\
\text { company boundaries and even } \\
\text { integrated supply chains, and it } \\
\text { supports the creation of dynamic } \\
\text { value networks. Industry } 4.0 \\
\text { solutions are actively used and } \\
\text { embedded in the company's strategy. } \\
\text { Level V-Optimized Full } \\
\text { Digitalization. The company is a } \\
\text { model for Industry } 4.0 \text {. It works } \\
\text { closely with its business partners } \\
\text { optimizing common processes and } \\
\text { value networks. }\end{array}$ & $\begin{array}{l}\text { Organization } \\
\text { Network of organizations }\end{array}$ & $\begin{array}{l}\text { Focus on the IT landscape } \\
\text { - General measures to enable } \\
\text { phase transitions }\end{array}$ \\
\hline $\begin{array}{l}\text { IMPULS Lichtblau } \\
\text { et al. (2015) [141] }\end{array}$ & $\begin{array}{l}\text { Six stages: } \\
\text { 0. Outsider } \\
\text { 1. Beginner } \\
\text { 2. Intermediate } \\
\text { 3. Experienced } \\
\text { 4. Expert } \\
\text { 5. Best score }\end{array}$ & $\begin{array}{l}\text { Six dimensions: } \\
\text { 1. Strategy and organization } \\
\text { 2. Smart factory } \\
\text { 3. Smart operations } \\
\text { 4. Intelligent products } \\
\text { 5. Data-driven services } \\
\text { 6. Workforce }\end{array}$ & $\begin{array}{l}\text { - Online self-assessment } \\
\text { - Outlining activities during } \\
\text { the transition phase }\end{array}$ \\
\hline $\begin{array}{l}\text { Azevedo, Santiago } \\
\text { (2019) [142] }\end{array}$ & $\begin{array}{l}\text { Six stages: (ACATECH) } \\
\text { 1. Computerization } \\
\text { 2. Connectivity } \\
\text { 3. Visibility } \\
\text { 4. Transparency } \\
\text { 5. Predictability } \\
\text { 6. Adaptability }\end{array}$ & $\begin{array}{l}\text { Six dimensions: } \\
\text { 1. Products and services } \\
\text { 2. Manufacturing } \\
\text { 3. Business model } \\
\text { 4. Strategy } \\
\text { 5. Supply chain } \\
\text { 6. Interoperability }\end{array}$ & $\begin{array}{l}\text { - Dimensions combined } \\
\text { transversely with stages } \\
\text { - Inclusion of matemathical } \\
\text { methods to measure the } \\
\text { maturity level }\end{array}$ \\
\hline $\begin{array}{l}\text { Schumacher, Nemeth, } \\
\text { Sihn (2019) [143] }\end{array}$ & 10-step approach to assessment & $\begin{array}{l}\text { Assesses the maturity of } 65 \\
\text { critical success factors in } \\
\text { Industry } 4.0 \text { grouped into eight } \\
\text { sections: Technology, Products, } \\
\text { Customers and Partners, Value } \\
\text { Creation Processes, Data and } \\
\text { Information, Corporate } \\
\text { Standards, Employees, Strategy } \\
\text { and Leadership }\end{array}$ & $\begin{array}{l}\text { Model focuses on the } \\
\text { assessment and guidance of } \\
\text { industrial companies } \\
\text { manufacturing discrete } \\
\text { goods with a focus on } \\
\text { in-house value creation as } \\
\text { detailed process } \\
\text { understanding in } \\
\text { administration, production, } \\
\text { and logistics is required. }\end{array}$ \\
\hline
\end{tabular}


3.3. A Method for Diagnosing the Level of Maturity of Implementing Industry 4.0 Solutions in Selected Functional Areas of Management of Automotive Enterprises

As already mentioned above, the definition of the Industry 4.0 initiative adopted in this work was based on one of the management theories, which is the value chain of Porter [145]. Porter distinguished two types of value-creating activities: basic activities and supporting activities. The basic activities include logistics in procurement, operations (production), logistics in distribution, marketing, and sales, after-sales service. Supporting activities include company infrastructure, human resources, technical development, and procurement. All these activities make up the value chain, which is treated as a tool for distinguishing, among all the tasks performed by buyers, suppliers and companies, which generate separate but interrelated activities that are a source of value. The components of the value chain taking into account the social aspect of the Industry 4.0 concept have become the basis for determining the scope of maturity assessment of enterprises (i.e., activities in the nomenclature of components of the value chain). Eventually, the model developed includes six functional areas, i.e., management of production, logistics, quality, human resources, social and environmental responsibility, and product innovation.

The model developed by the authors assumes five levels of maturity based on the maturity model proposed by Huber [51]. We think that the five levels of maturity conception is a good tool to measure the maturity within functional areas. The conception is universal, and it is useful to measure the level of engagement of the organization in the case of particular functional area. We thought that to measure those areas, we can use the maturity model with a five-step assessment of the particular area adjusted to the analyzed problem connected with Industry 4.0.

Each maturity level was characterized by statements describing the attributes of successive levels of digitalization of selected functional areas. The basis for the statements was the literature review presented in the previous section of this article. The statements were compiled into a survey questionnaire and are included in Appendix A. In the second stage of the research, an assessment of the maturity level of automotive production enterprises was carried out by means of survey research with the use of a questionnaire (Appendix A). The managers and employees selected a group of statements that best characterized the maturity level of the implementation of Industry 4.0 solutions in particular functional areas of the enterprises. The condition of confirming all the tests describing a given functional level allowed for the award of a grade (on a five-point scale). The maturity levels assigned to the group of statements were completed in the "table of respondent's answers" in Appendix A. Moreover, the table of answers included questions concerning the type of components/parts/subassemblies supplied by the enterprise (on this basis, the surveyed sample was divided into suppliers occupying different places in the supply chain). It was assumed that suppliers of subsystems (e.g., engine, wiper system, engine cooling system, etc.) are located closer to OEMs; i.e., they are first-tier suppliers and a second group of component suppliers (metal parts, rubber parts, etc.) who in turn are more likely to occupy positions at the top of supply chains i.e., second-tier suppliers. The size of the company (understood according to the Act of 6 March 2018-Business Law) was another criterion dividing the surveyed companies this time into three groups, i.e., large, medium, and small.

\subsection{Research Sample}

The research was conducted on a sample of 50 respondents representing 50 companies from the automotive industry located in Poland (including 34 large, 12 medium-sized, and 4 small companies). The survey was addressed to engineering staff of the surveyed companies. The respondents were selected by the method of purposive selection. The selection criteria were work experience in an automotive company and engineering education. The research was conducted in April and May 2020. The questionnaire was sent through e-mails and the same way was used to obtain the completed forms. The details of the study sample are given in Table 2. 
In the next step, the collected data were subjected to statistical analysis. Due to the small research sample, descriptive statistics was used for the analysis. In the third and final stage of the research, on the basis of the obtained results and the literature review, recommendations for managers were presented concerning possible and future actions that give a chance to achieve higher levels of maturity.

Table 2. Characteristics of the research sample.

\begin{tabular}{|c|c|c|c|c|c|}
\hline \multicolumn{6}{|l|}{ Research sample } \\
\hline & Large companies & Medium-sized companies & Small companies & Total & Percentage share \\
\hline OEM & 1 & & & 1 & $2 \%$ \\
\hline Subsystem suppliers (P1) & 13 & 3 & 0 & 16 & $32 \%$ \\
\hline Component suppliers (P2) & 20 & 9 & 4 & 33 & $66 \%$ \\
\hline \% Subsystem suppliers (P1) & $26 \%$ & $6 \%$ & $0 \%$ & & $0 \%$ \\
\hline \% Component suppliers (P2) & $40 \%$ & $18 \%$ & $8 \%$ & & $0 \%$ \\
\hline Sum & 34 & 12 & 4 & 50 & $100 \%$ \\
\hline Place in supply chain & \multicolumn{3}{|c|}{ Class of automotive parts } & & $\begin{array}{c}\text { Number of } \\
\text { enterprises surveyed }\end{array}$ \\
\hline P0 & \multicolumn{3}{|c|}{ Car assembly plant } & & 1 \\
\hline P1 & \multicolumn{3}{|c|}{ Engine } & & 1 \\
\hline P1 & \multicolumn{3}{|c|}{ Drive } & & 1 \\
\hline P1 & \multicolumn{3}{|c|}{ Chassis } & & 3 \\
\hline P1 & \multicolumn{3}{|c|}{ Wheels/tires } & & 1 \\
\hline P1 & \multicolumn{3}{|c|}{ Body } & & 2 \\
\hline P1 & \multicolumn{3}{|c|}{ Technological components for building a car } & & 4 \\
\hline P1 & \multicolumn{3}{|c|}{ Lamps } & & 2 \\
\hline P1 & \multicolumn{3}{|c|}{ Wiper systems } & & 1 \\
\hline P1 & \multicolumn{3}{|c|}{ Steering gear } & & 1 \\
\hline P1 & \multicolumn{3}{|c|}{ Engine cooling systems } & & 1 \\
\hline P2 & \multicolumn{3}{|c|}{ Metal parts } & & 9 \\
\hline P2 & \multicolumn{3}{|c|}{ Rubber parts } & & 3 \\
\hline P2 & \multicolumn{3}{|c|}{ Rubber-metal parts } & & 3 \\
\hline P2 & \multicolumn{3}{|c|}{ Plastic parts } & & 9 \\
\hline P2 & \multicolumn{3}{|c|}{ Consumables } & & 3 \\
\hline P2 & \multicolumn{3}{|c|}{ Vehicle protective measures } & & 1 \\
\hline P2 & \multicolumn{3}{|c|}{ Sheathing } & & 1 \\
\hline P2 & \multicolumn{3}{|c|}{ Electrical equipment } & & 3 \\
\hline & \multicolumn{3}{|c|}{ Total } & & 50 \\
\hline \multicolumn{6}{|c|}{ P0_OEM/assembly plant; car manufacturer } \\
\hline \multicolumn{6}{|c|}{ P1-first-tier supplier; closer to the assembly plant in the supply chain } \\
\hline P2—second-tier supplier; furt & from the assembly & ant & & & \\
\hline
\end{tabular}

Source: Own study.

\section{Results}

This paper attempts to diagnose the level of maturity of companies in the automotive industry in implementing Industry 4.0 solutions. The level of maturity was assessed through the analysis of functional management areas. The proposed maturity model includes six management areas:

1. The Digitalization of Production System (DPS)

2. The Digitalization of the Logistics System (DLS), 
3. The Maturity of the Quality Management System (QMS),

4. The Maturity of Human Resources Management (HRM),

5. The Intensity of CSR Activities (ICSR),

6. The Commitment to Product Innovation Development (CPID).

The results of the assessment of individual areas are presented in the following Figures 2-5. In order to achieve the research objective set out in the article, we try to find the answer to the question: What is the level of maturity in implementing Industry 4.0 solutions in selected functional management areas of automotive companies operating in Poland? The assessment of the enterprise maturity level consisted of assessments from six functional areas. No averages were calculated from these six ratings (to provide a cumulative rating that indicates the maturity of the enterprise). The results presented in the figures are average scores obtained from the functional areas of the surveyed enterprises. The basis of the generalized conclusions was that the company cannot be at level 5 , showing only full maturity in the implementation of 4.0 solutions in production or in logistics and while not showing maturity (assessed at 5) in other functional areas. Using the conclusions of the authors of the "Maturity Assessment Methods in Implementing Industry 4.0 Solutions" (see Table 1), we believe that a company cannot achieve the full digitization scenario at level 5 if it cannot cope with one of the assessed criteria.

The results obtained were based on the calculation of average scores for individual areas. The results are presented in Figure 2.

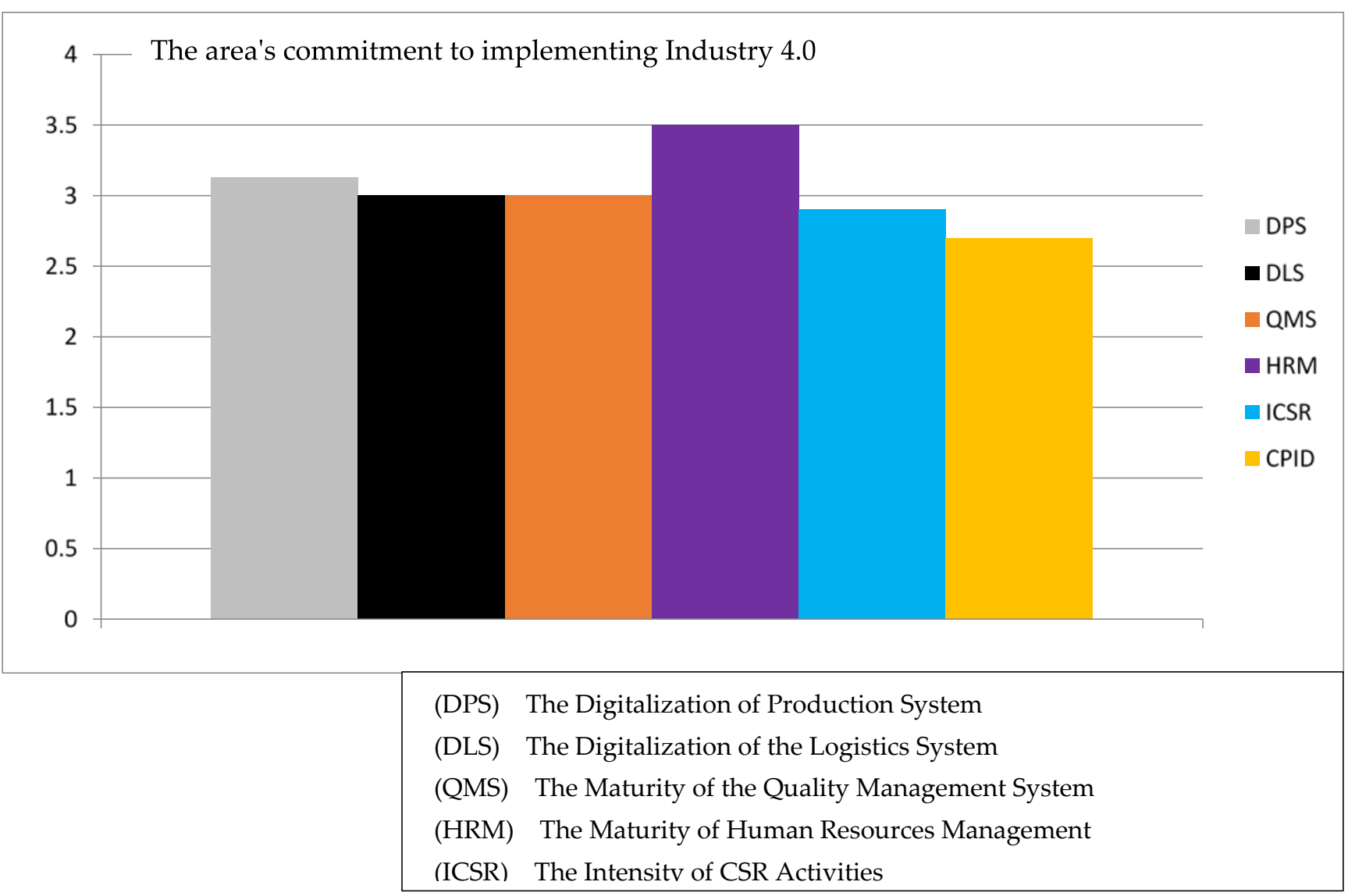

Figure 2. Maturity level of companies in implementing Industry 4.0 solutions assessed in six management areas (average scores according to indications). Source: own work based on primary data.

As it can be seen in Figure 2, the average score for all areas oscillates around 3. The area of human resources management received the highest score (3.5), and the area of involvement in the development of product innovation received the lowest (2.7), which may mean that so far, the main objective of implementing 4.0 technologies in production 
processes has been their efficiency and effectiveness, and less often, the developed product innovation. However, this may be changing as a result of the support of the automotive industry by the government program for electromobility and support for innovation in general.

The next research question that we wanted to answer was as following: Does the level of maturity achieved vary depending on the size of the company, its place in the value chain, and the class of the automotive part produced? The aggregate results of the research are presented in Figures 3-5.

As we can see in Figure 3, the highest level of maturity in implementing Industry 4.0 solutions is represented by large enterprises (average 3.6). In large enterprises, the ICSR area was rated the highest (4.2), and the CPID area was rated the lowest (3.1). The remaining areas received scores from 3.5 to 3.6. The second-largest level of maturity was shown by medium-sized companies with an average score of 2.96. The surveyed representatives of medium-sized companies rated the HRM area the highest (3.3), and the ICSR area received the lowest (2.7). Assessments of the maturity level of the remaining areas oscillate around the grade of 3.0. The level of maturity in the implementation of Industry 4.0 was rated the lowest in small companies-the average rating is 2.5. The highest scores were given to the HRM area (3.2), and the lowest scores were given to the ICSR and CPID areas (2 points each). The ratings of the remaining areas range from 2.5 to 2.75 .

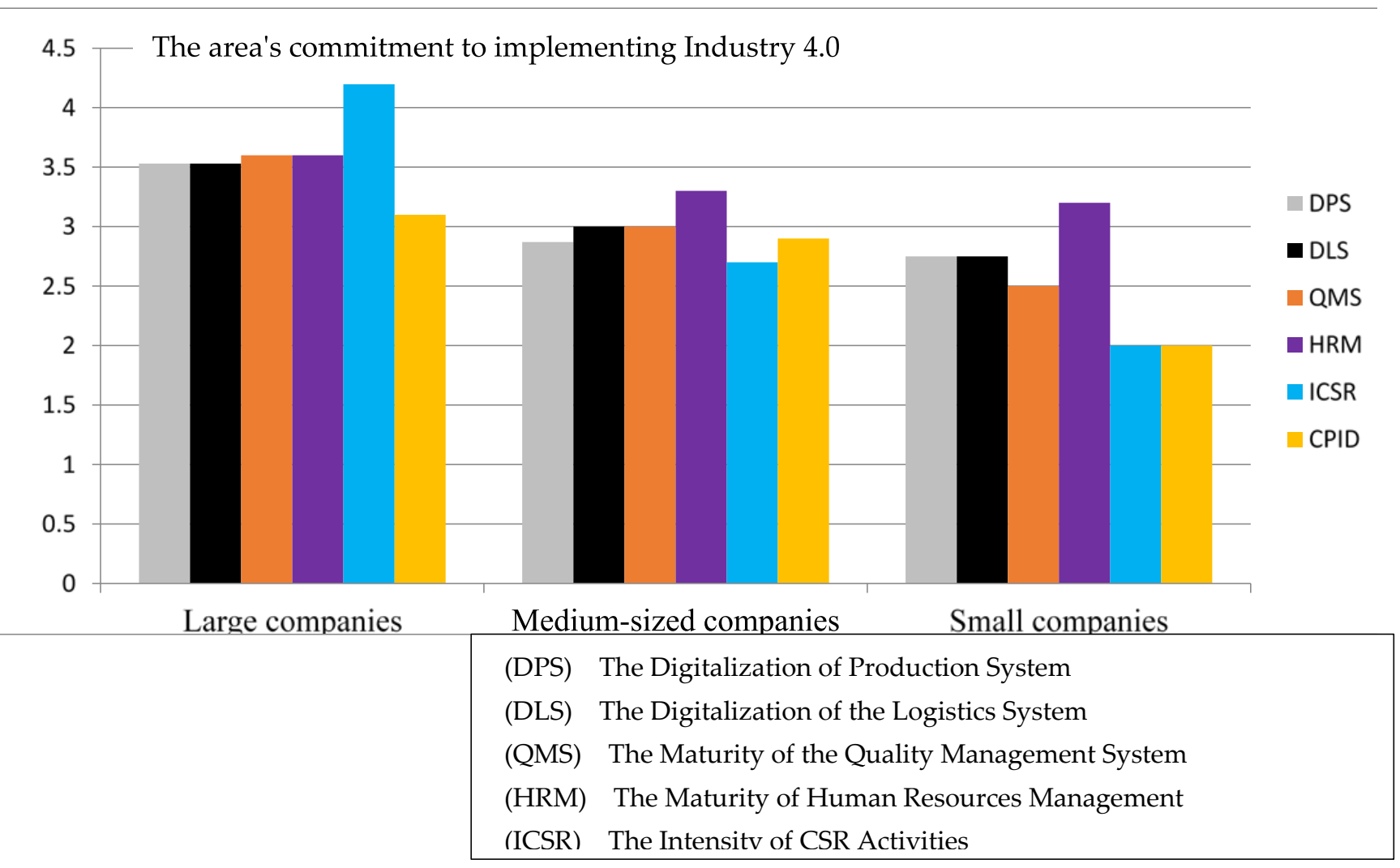

Figure 3. Maturity level of companies in implementing Industry 4.0 solutions assessed in six management areas, presented with a division into the size of the surveyed enterprises (average scores according to the indications). Source: Own work based on primary data.

With regard to the division into subsystem suppliers and component suppliers (Figure 4), relatively higher scores were awarded in the group of subsystem suppliers (average 3.35), with the ICSR area being the highest (3.9), and the HRM area being the lowest (2.95). The average grade for the maturity level for component suppliers is 3.0, with the lowest grade for the CPID area (2.1) and the highest scores for the DPS area (3.4) and the HRM area (3.3). 


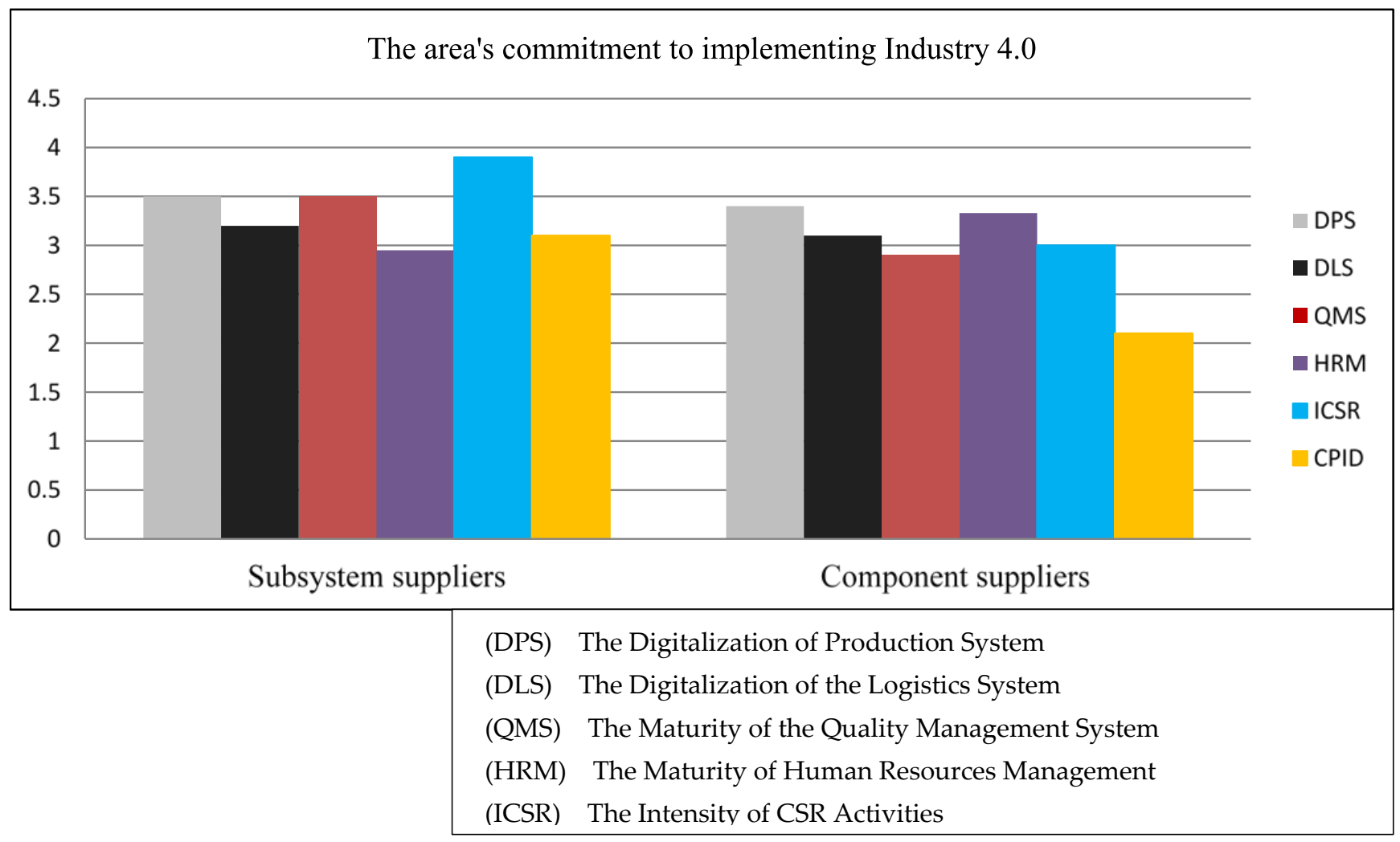

Figure 4. Maturity level of companies in implementing Industry 4.0 solutions assessed in six management areas, presented by suppliers of subsystems and components (average score by indication). Source: Own work based on primary data.

As for the classes of manufactured parts (Figure 5), the highest level of maturity was declared by chassis manufacturers (average 4.42), followed by technological elements manufacturers (average 3.57) and body manufacturers (average 3.52). The tire and wheel manufacturers were definitely at the lowest level of maturity (average 2.25).

The analysis carried out in the paper showed differences in the maturity of enterprises in implementing Industry 4.0 solutions. This finding is the result of assessing functional areas of management supporting the implementation of Industry 4.0 solutions. The level of maturity was assessed the highest (in relation to all functional areas) in large companies, among manufacturers of subsystems (with the exception of the area of human resources management) and manufacturers of such classes of manufactured parts as engines, bodies, electrical, and technological elements for building cars. 
The area's commitment to implementing Industry 4.0

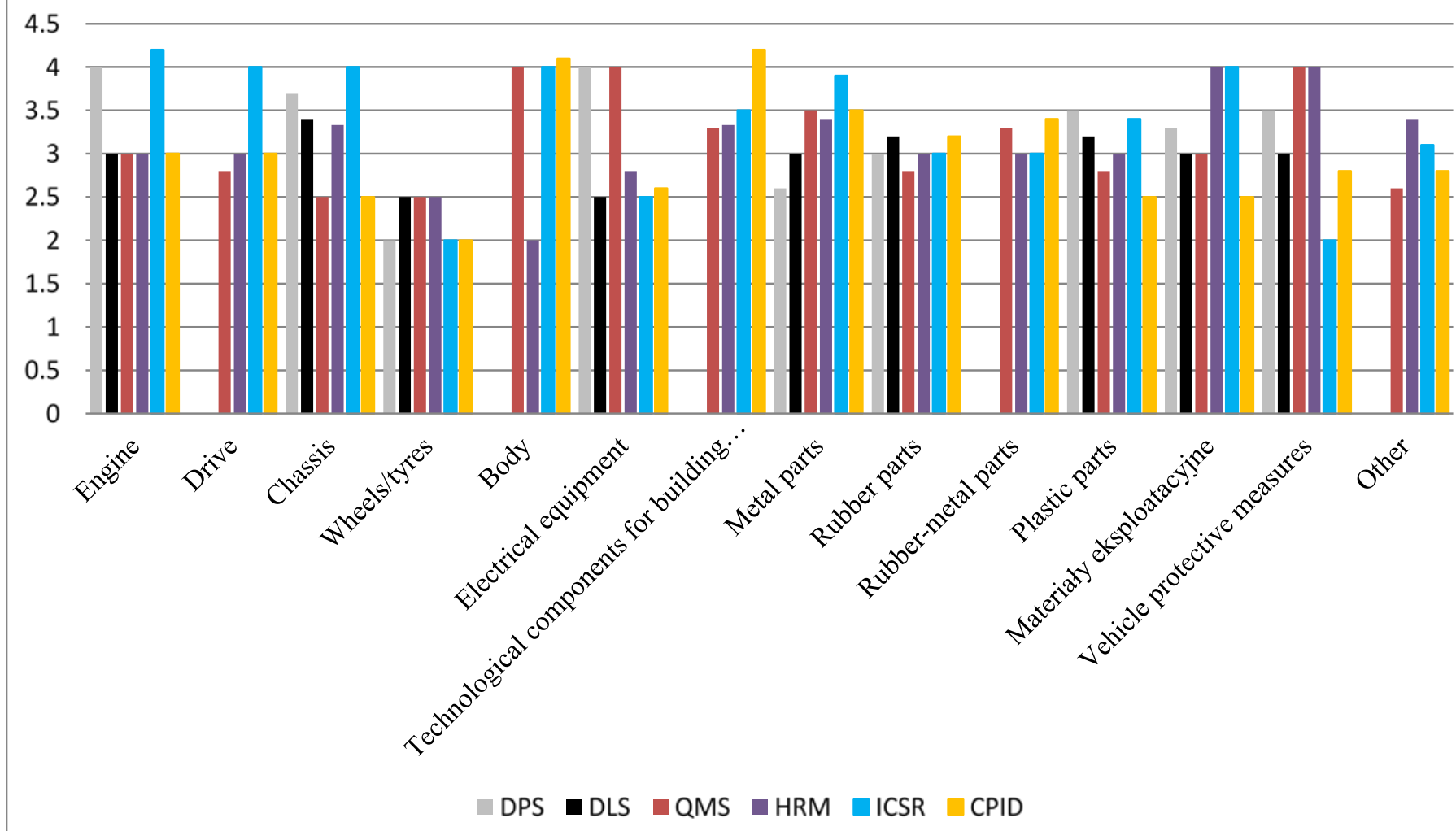

(DPS) The Digitalization of Production System

(DLS) The Digitalization of the Logistics System

(QMS) The Maturity of the Quality Management System

(HRM) The Maturity of Human Resources Management

(ICSR) The Intensity of CSR Activities

Figure 5. Maturity level of companies in implementing Industry 4.0 solutions assessed in six management areas, presented with a division of enterprises according to the class of manufactured parts (average score according to indications). Source: Own work based on primary data.

The answer to the question, "What actions should be taken by enterprises in order for them to achieve higher levels of maturity in implementing Industry 4.0 solutions?" requires the formulation of recommendations. For this purpose, it is first necessary to identify the maturity level of a company in the implementation of Industry 4.0 solutions. Self-assessment can be done using a questionnaire (Appendix A), containing tools to assess the maturity level of a company in the implementation of Industry 4.0 solutions (when tested in the presented research, it was met with interest and recognition of the respondents). Therefore, the proposed tool, containing patterns and standards concerning the implementation of Industry 4.0 solutions, may be used to conduct audits, the results of which may be presented graphically in the form of a matrix (Figure 6). Systematic audits will allow monitoring the progress of involvement of the examined areas in achieving successive levels of maturity in implementing Industry 4.0 solutions. An example of a matrix for assessing the company's involvement in Industry 4.0 is presented in Figure 6. 


\begin{tabular}{|c|c|c|c|c|c|c|c|}
\cline { 1 - 6 } Levels & \multicolumn{9}{|c|}{} \\
\hline 5 & & & & & & & \\
\hline 4 & & & & & & & \\
\hline 3 & & & & & $X$ & & \\
\hline 2 & & $X$ & $X$ & $X$ & & & \\
\hline 1 & $X$ & & & & & $X$ & X \\
\hline Audited areas & DPS & DLS & QMS & HRM & ICSR & CPID & Other areas \\
\hline
\end{tabular}

(DPS) The Digitalization of Production System

(DLS) The Digitalization of the Logistics System

(QMS) The Maturity of the Quality Management System

Figure 6. Example matrix for assessing the maturity level of a company in implementing Industry 4.0 in selected management areas. Source: Own work.

The results obtained in the conducted research (average scores in selected areas) can be treated as the results of an audit conducted among the employees of 50 automotive companies located in Poland and presented in a matrix (Figure 7).

\begin{tabular}{|c|c|c|c|c|c|c|}
\hline Levels & & & & & & \\
\hline $\mathbf{5}$ & & & & & & \\
\hline $\mathbf{4}$ & 4 & 4 & 4 & 4 & 4 & \\
\hline $\mathbf{3}$ & 3 & $\mathbf{3}$ & $\mathbf{3}$ & $\mathbf{3}$ & $\mathbf{3}$ & $\mathbf{3}$ \\
\hline $\mathbf{2}$ & & & & & & $\mathbf{2}$ \\
\hline $\mathbf{1}$ & & & & & & \\
\hline
\end{tabular}

Figure 7. Matrix for evaluating the level of maturity of automotive companies in the implementation of Industry 4.0 in the six examined areas (average scores according to the indications). Source: Own work.

\section{Discussion}

Problems connecting with the maturity level of Industry 4.0 implementation in automotive companies is very closely related with sustainable development and the sustainable organization concept. The efficient and adjusted to Industry 4.0 condition automotive company should be sustainable from many points of view, especially ecological, technological, financial, and human resource management. The higher level of maturity of the company leads to the higher level of its sustainability.

The first research question was connected with key challenges faced by companies operating in the automotive industry. Based on the [146-148] analysis, we think that the main challenge for companies doing activity in the automotive industry nowadays is digital transformation of their processes and the whole economy. This digital transformation is the 
main part of the so-called Industry 4.0 implementation and must be done by automotive organizations to achieve a sufficient level of competitiveness in this very competitive market. The increase of digitalization of the organizational processes also leads to an increase of organization sustainability, because the digitalization of all the data enables the better analysis of the environmental impact of the production and also enables careful life cycle assessment analysis. The digitalization is a big challenge because we should not only adjust the production systems to new situations but also change the mentality of workers toward sustainable digital production. The change in business and technology leads to the full digitalization of many activities and requires a good level of digital competences of organizations and employers.

In addition, the increase in the number of integrated multimedia units in the cars should provide many challenges with the better connectivity with environment and the implementation of the sustainable organization conception. The situation needs the development of new, more efficient ways of collaboration between production and logistics. This collaboration is not possible without the digitalization of production and logistic processes. To meet the challenges of modern automotive sustainable value chains, higher levels of maturity are necessary.

The second research question was connected with the level of maturity in the implementation of Industry 4.0 solutions in selected functional management areas of automotive enterprises operating in Poland.

The first two analyzed areas of commitment to implementing Industry 4.0 were the digitalization of the production system and the digitalization of the logistic system. Based on available data from many different sources (equipment, machines, products, customers, etc.), moving to a higher level of maturity will require analytics based on large datasets. On the basis of analytical results, production and logistics processes will be optimized in a sustainable way in such dimensions as process quality, energy consumption, equipment, and people productivity. This requires, among other things, the implementation of data processing solutions in the cloud. At the current level, only a certain proportion of machines and equipment are networked. In the future, automotive suppliers will have to implement solutions allowing the identification and communication using standard technologies even at the level of semi-finished products. Such solutions will allow devices to communicate not only with each other but also with a more centralized system. The problem (for companies in Poland) may be the lack of developed communication standards or interfaces for IoT communication and outdated machine parks. This type of communication will have a positive impact on sustainable development because the digital communication has a lower negative environment impact $[9,10,13]$.

The duplication of the physical world in the digital world (digital twin) is the next task to move to the next level of maturity in the implementation of Industry 4.0 solutions. The creation of CPS will make it possible to carry out simulations not only at the stage of designing products, materials, or production processes, but it will also make it possible to carry out simulations using real-time data to reflect the physical world (including machines, products, and people). Operators will test and optimize machine settings for new products on the virtual production line even before physical commissioning, thereby reducing the equipment setup time and improving product quality [20-22].

The above steps will allow manufacturers and their suppliers to move closer to full vertical and horizontal sustainable value chain integration. In the case of vertical integration, internal value chain processes will be connected-executing more efficiently primarily between departments and functions. On the other hand, at the value chain level, integration will extend to external partners. At this stage, sustainable supply chains will become transparent in their operations [149]. It is recommended to optimize activities along the chain using analytics solutions. Data collection must span the collaborating ecosystems [150]. It is recommended that all of the above tasks begin at the strategic level in a deliberate manner, taking the form of a plan, with an accepted vision of digital change in all areas of the company [133,151-153]. 
As in the case of other areas, the third analyzed area was quality management systems. On the basis of our research, we can say that in the case of quality, the level of maturity in implementing Industry 4.0 solutions of the surveyed automotive suppliers is not high. The average level of maturity of the quality management system in the surveyed organizations was slightly above 3.3 on a 5-point scale. This is a level that can be described as decent-it means that the organizations base their activity on the principles of process management, ensure a high repeatability of activities, and improve products and processes. However, they lack a comprehensive system for measuring all processes, trend analysis, or a comprehensive approach to creating new solutions. Similar results were obtained by Schumacher $[139,143]$. Although he did not include quality as a separate component in his model, nevertheless, those elements of the analyzed model that concerned quality are included in areas such as product, operations, and technology. The situation is similar in the case of studies conducted by other authors [23,25,43,154-162].

Improving the level of maturity for Industry 4.0 implementation with respect to quality is important because, as shown by Şener's analysis [163,164], it positively increases the level of product quality and productivity, improves organizational performance, reduces the number of defects that occur, and improves employee engagement.

It is worth noting that the larger the organizations, the higher the maturity level of their quality management systems. For small organizations, it is 2.5; for medium organizations, it is 3.62 , while for large organizations, it is 3.83 , which is already approaching level 4 , which can be described as good. The study shows that in terms of quality management system performance, small companies in the automotive industry in particular still have some way to go to adapt their system to the requirements of Industry 4.0. For example, similar results were obtained by Amaral and Peças $[165,166]$. The maturity level for subsystem suppliers is clearly higher at 3.5 compared to component suppliers, for which it is 2.92 .

The fourth analyzed functional area was human resource management. The conducted research revealed a rather low level of competence of automotive industry employees in relation to Industry 4.0 solutions, which means that they are not well enough prepared to implement new technologies in a sustainable way [167-170]. The obtained results confirm the fact that the competency gap mentioned in Section 2.5 is also quite common in other industries. According to the surveyed employers in the automotive industry, in order to fill the competence gap, it is necessary to develop directional education for young people (both engineers and managers), as well as systematic training of employed workers [53-60]. Especially automotive organizations should concentrate on the sustainable implementation of new informatics solutions by peoples. Similar proposals are suggested by many authors, pointing to the need for systemic changes in human resources education, which should go in the direction of closer cooperation between employers and schools and universities with regard to the creation of curricula, teaching methods, content, and form of professional exams $[54,61,71,171,172]$. An example in this regard is the CDIO (ConceiveDesign-Implement-Operate) program, which was developed by leading American and Swedish technical universities [173]. Diaz and Flores [174] propose the inclusion of universities in the automotive cluster (Nuevo Leon) as an educational institution, supporting the formation of new employee competencies for Industry 4.0. This inclusion of universities brings better sustainability in the functioning of automotive clusters because of bringing a new, independent view on the whole production processes. In addition, learning factory 4.0 concepts, based on scenarios oriented to the learning problems of future manufacturing engineering, are created and piloted in selected companies [174,175]. Furthermore, due to the international interconnectedness of suppliers and collaborators in automotive value chains, it is highly advisable to standardize competency requirements and standardize professional positions. An important initiative in this regard is the Development and Research on Innovative Vocational Education Skills (DRIVES) project, in the framework of which automotive companies, universities, and industry associations develop sustainable sectoral cooperation in the field of professional qualifications for the automotive industry at the European level $[176,177]$. The development and implementation of modern 4.0 
technologies in a sustainable way enforces the need for lifelong learning, in view of which a new strategic approach to comprehensive human resource management will also be needed $[51,178]$. It is recommended to implement new solutions in a sustainable way smoothly by gradually replacing existing jobs with new ones, due to the serious social and psychological barriers related to the acceptance of Industry 4.0. [76,179].

The next (fifth) functional area of implementing Industry 4.0 was the intensity of CSR activities. The implementation of CSR is a very important part of a modern sustainable organization. The conducted research showed a rather low level of maturity of Industry 4.0 implementation in the context of the intensity of CSR activities of the automotive industry. This means that the engineering staff recognizes the need for sustainable development of companies and manufactured products, but it is just beginning to use Industry 4.0 solutions to implement social and environmental programs and to measure the effectiveness of these implementations. This initial commitment was also shown by [82].

The automotive corporations belong to the Business Social Compliance Initiative (BSCI) association, but only those certified by the BSCI show the effectiveness of implementing Industry 4.0 solutions and at the same time the transparency of responsibility for managing the CSR sphere [96]. The results of the surveys show that the level of maturity 4.0 analyzed in the area of CSR (automotive companies located in Poland) is different depending on the size of the company and its place in the value chain. Surveys show that large companies, especially automakers and first-tier suppliers, cooperate with cooperators on issues of solving environmental and social problems. They use for this purpose Industry 4.0 solutions, e.g., Big Data (for monitoring ethical programs, organizing training, auditing from compliance with standards, identifying causes of negligence, verifying codes of conduct, etc.) [83].

The third research question was connected to analysis: Does the achieved level of maturity vary depending on the functional area, class of the manufactured automotive part, company size, or its place in the value chain? The results of the study showed that as the size of the company increases, the level of digitalization maturity increases, both in production and logistics subsystems. The medium-sized companies in the sample have not yet reached the full third level, and the large companies are halfway to the fourth level of digitalization of production and logistics. This means that climbing to the next levels will require a number of actions from them. Firstly, the level of saturation with automatons or robots must increase but above all with autonomous devices that can cooperate and communicate with each other. New generations of increasingly inexpensive collaborative robots will increase the efficiency of labor-intensive production and logistics tasks (picking, sorting, inspection, storage, etc.).

The last analyzed functional area was the commitment to product innovation development. The survey shows that the level of maturity in implementing Industry 4.0 technologies is rated quite low by Polish automotive employees/engineers. They rate large companies (including car manufacturers and subsystems) only slightly better. Bringing all the assessments to the average and using the assessment criteria proposed in the research tool, it can be concluded that the automotive industry is increasing its maturity in implementing Industry 4.0, at the same time making attempts to develop product innovations. For most of the quoted researchers, the application of Industry 4.0 solutions is the basis for the implementation of product innovation and vice versa. In their opinion, a new production technology gives rise to a new product solution, and a new product concept prompts the search for new manufacturing technologies.

The fourth research question was about actions to take by a company to achieve higher maturity levels in implementing Industry 4.0 solutions. Drawing up a list of recommendations, for companies striving for maturity in the implementation of Industry 4.0 solutions and at the same time wanting to improve product innovation performance, they recommend changing the business model into one that is more sustainable so that the enterprise operates both in an integrated supply chain (based cooperation on long-term contracts signed with reliable market partners) but also joins dynamically changing innovative 
networks developing new products [140]. There are other model changes: the use of cluster support and integrative knowledge platforms supporting new product development [117]; managing a portfolio of product innovations generated in a network of collaborating companies; protecting intellectual property using blockchain technology: [179]; developing new strategies for commercializing innovative solutions, applying marketplace platforms to B2B e-commerce; self-assessment of the efficiency of implementation of innovation, procurement, and production processes; and the introduction and use of KPIs allowing for periodical measurement of innovation, purchasing, and production efficiency [112]. It is important when creating KPIs to be open to cooperation in the R\&D area, changes influencing the mutual adjustment of business models and assets, and the improvement of common innovation processes.

Based on our research in the future, in order to improve the maturity level of implementing sustainable Industry 4.0 solutions for the automotive industry companies, the following are necessary:

- Improve the level of digitalization of all quality data in particular for operational processes;

- Use quality management methods including statistical methods for detailed analyses of quality data;

- Use artificial intelligence and machine learning to analyze quality data, e.g., to analyze the causes of occurring problems;

- Develop a comprehensive measurement system for all processes in the organization;

- Improve design processes for new products taking into account quality requirements and Industry 4.0 requirements.

Answering the question of what priority CSR activities should be undertaken by automotive companies in order for them to reach higher levels of maturity in implementing sustainable Industry 4.0 solutions recommends: [82-84]

- Developing and applying risk management models based on existing standards (ISO 9001, ISO 140001, ISO 45001, ISO 27001), or perhaps create entirely new ones growing out of the risk-based thinking (RBT) stream [104];

- Creating framework requirements for required skills, new ways of organizing work, interactions, and synergies in the human-machine-environment interface $[180,181]$;

- Providing security for computer and communication systems, preventing attacks by hackers who would want to harm society or the environment [182,183];

- Applying Big Data to monitor CSR activities in companies, supply chains, and networks.

Referring to the fact that the preliminary observations on the level of maturity of Industry 4.0 in Poland were more negative than the results obtained, one should take a closer look at the surveyed sample of enterprises. In the surveyed sample, small and medium-sized enterprises account for $9 \%$ of the respondents. It was the assessment of the level of Industry 4.0 implementation in SMEs that influenced the initial opinions about the automotive industry in Poland. The results from the entire test sample and the calculated standard deviations indicated a much higher assessment of the level of Industry 4.0 implementation.

\section{Conclusions}

The fourth industrial revolution, known as Industry 4.0, was a cause of many changes in many sectors of the economy [2]. The automotive industry was one of the first industries that started to implement advanced 4.0 technologies in the production process of innovative cars [3]. Multinational automotive companies are implementing new business models, expecting an appropriate level of advancement in the implementation of modern technologies and solutions from their partners, suppliers, and sub-suppliers in the value chains [4]. For automotive companies located in Poland, which are primarily manufacturers of subassemblies and automotive parts, Industry 4.0 is both an opportunity and a great 
challenge. The implementation of Industry 4.0 solutions requires complex changes in all areas of a company's activity, not only in the production technology area.

The main objective of this study was an attempt to diagnose the level of maturity of automotive enterprises located in Poland in the implementation of Industry 4.0 solutions in selected functional areas of management (production and logistics management, quality, human resources, social and environmental responsibility, product innovation). The conducted survey showed that the analyzed management areas are at the third level of maturity in implementing Industry 4.0 (except for product innovation management, which is at the second level). In order to meet the challenges of modern automotive value chains, higher levels of maturity are necessary. Accordingly, appropriate measures were recommended in the analyzed management areas. In the areas of production and logistics of enterprises that are producing components and parts, it is recommended to take measures aimed at the full vertical and horizontal integration in value chains.

First of all, it is postulated to increase the level of robotization and the introduction of intelligent devices allowing for online data collection and communication between machines and means of transport, which will enable the use of such tools as Big Data, cloud computing, or the construction of CPS. A necessary condition for the digitalization process is the implementation by automotive companies (especially small and mediumsized ones) of Enterprise Resource Planning (ERP) systems, Manufacturing Execution Systems (MES), and Computerized Maintenance Management Systems (CMMS), offering support for maintenance or warehouse operations.

In the area of quality management, the most important stimulus for the implementation of Industry 4.0 solutions is the implementation of the IATF 16949 standard [28,29]. This standard is currently necessary for the companies manufacturing car components and parts to maintain their competitive position in the automotive supply chain. Especially, the standard involves the use of numerous quality management methods and tools, the implementation of which leads to improvements in the quality of manufactured products $[32,33]$. Examples include the digitalization and application of Failure Mode and Effects Analysis (FMEA) (tools for risk management) and Advanced Product Quality Planning (APQP) (tool for planning product and process design and development) [38,39]. In the area of human resources management, it is postulated that automotive companies should hire appropriately qualified engineers and managers, monitor the needs for training and development of employees, and improve the system approach to motivate employees, with particular emphasis on management style. This requires systemic changes in industry education programs at all levels, which should be focused on greater involvement and close cooperation between school/university-employer-student, for which the CDIO program, developed by leading Swedish and American technical universities, may serve as a model and inspiration. Due to the international interconnectedness of supplier and co-operator networks in the automotive value chains, there is a need to unify the system and create standards for competence requirements for engineering staff on an international scale.

In the era of implementing Industry 4.0 solutions, it is necessary to revise the CSR policy in the direction of creating value for stakeholders. Handling Industry 4.0 technologies and tools by employees will require defining framework competencies and requirements. It is about building a safe environment for engineers to cooperate with robots, etc. It also seems necessary to develop and implement risk management models based on existing standards (ISO 9001, ISO 140001, ISO 45001, ISO 27001) or based on completely new standards, growing out of the RBT current [83].

In the area of product innovation development, it is recommended that automotive companies change their business models to hybrid ones, i.e., ones that would allow them to function effectively both in integrated supply chains and to develop innovative products in dynamically changing (rotating) innovative chains. Functioning in a creative, hybrid business model requires the use of many modern solutions, such as a simultaneous model of the innovation process, computerized, flexible production lines, the use of intelligent 4.0 technologies. 
The innovative approach in the research, comparing to other studies, is the inclusion of different functional areas of the organization in the assessment, which leads to a more comprehensive model for assessing the maturity of digital transformation of enterprises. Moreover, the developed maturity model can help to better understand the mechanisms, success factors, and detect patterns of digital transformation of manufacturing enterprises in their different functional areas. Based on the obtained results, it can be assumed that they will differ due to, for example, the size of the enterprise or places in the value chain. The maturity model can serve as a basis for managers to reflect on the company's current capabilities and its place in the transformation process toward Industry 4.0 and, consequently, subsequent decisions on appropriate strategies and action plans. The intention of the authors is to deepen the research project on the implementation of Industry 4.0 solutions in the automotive industry. There will be more literature review articles on Industry 4.0 maturity models and the level Industry 4.0 implementation assessment.

The present research, similar to others, has its limitations. The main ones are the small research sample and limitation to one industry from the one selected country. In the future, research on the maturity level of enterprises may be conducted on a larger sample, from various industries, taking into account additional moderating factors, such as the characteristics of the competitive environment, the complexity of offered products, or the legal environment.

Author Contributions: E.S., D.S., M.M., R.W. together prepared the conceptualization, methodology, validation, formal analysis, investigation, resources, data curation, writing-original draft preparation, writing - review and editing, and visualization. E.S. described and researched the area of CSR and innovation management. D.S. described and researched the area of human resources management. M.M. described and researched the area of production and logistics management. R.W. described and researched the area of quality management. E.S. exercised the supervision and project administration. All authors have read and agreed to the published version of the manuscript.

Funding: The analysis in this publication has been made in the course of the research project internal Silesian University of Technology project 13/040/BK/21/0095.

Institutional Review Board Statement: Not applicable.

Informed Consent Statement: Not applicable.

Data Availability Statement: Data are contained within the article.

Conflicts of Interest: The authors declare no conflict of interest.

\section{Appendix A}

Automotive industry survey on commitment to implementing Industry 4.0 solutions Research tool authors:

Assoc. Prof. Ewa Stawiarska; Assoc. Prof. Danuta Szwajca;

Prof. Radosław Wolniak; Dr. Mirosław Matusek Eng.

Faculty of Organization and Management

Silesian University of Technology

Ladies and gentlemen, engineers, and at the same time employees of companies in the automotive industry. We would like to ask you to complete a questionnaire survey on the maturity of an enterprise in implementing Industry 4.0 solutions. The research is being carried out for the purposes of a scientific thesis.

The high automation of business processes requires changes in management, work organization, quality, human resources, social and environmental responsibility, and innovation. The aim of the study is to assess the degree of transformation of these areas of the enterprise toward Industry 4.0 .

In the survey, we do not collect any data on the company name or data by which the company can be identified. The data collected will be processed into statistical summaries, which will provide the company with additional anonymity. We request that you provide truthful information and honest answers. 
Below, you will find six tables, in which the levels of a company's involvement in Industry 4.0 in various areas of the organization's functioning are distinguished. We kindly ask you to indicate the level of involvement in Industry 4.0 by reading the sentences that characterize each area. The condition of confirming all the tests describing a given functional level allowed for the award of a grade (on a five-point scale). Please put your assessment (1-5) of your company's involvement (in the six areas) in a collective "table of respondent's answers" placed at the end of the questionnaire. Please send the "respondent's table" back to: ewa.stawiarska@polsl.pl

Table A1. Criteria for evaluating the level of Digitalization of the Production System (DPS).

\begin{tabular}{ll}
\hline Levels & Level/Activity Characteristics \\
\hline - $\quad$ Production systems are automatically planned and controlled \\
- $\quad \begin{array}{l}\text { Machines and equipment communicate with each other through network services, } \\
\text { Level 5: }\end{array}$ \\
full digitalization
\end{tabular}

- Data from production systems are analyzed and evaluated to plan and control production processes

Level 4:

interdepartmental digitalization

Level 3:

departmental digitalization

Level 2:

basic digitalization

Level 1:

digitalization initiation
- Machines and equipment have access to the Internet

- Unified internal communication (communication rules, data, and information format) of production with other functional and organizational units

- Mobile devices are used to exchange data and information in human-machine interaction

- Data from production systems are analyzed to monitor production processes

- The devices communicate via an industrial Ethernet network

- Internal communication (communication rules, data and information format) on the production level is standardized

- Monitoring and control of the production processes can be carried out centrally and locally

- Data from production systems is exclusively generated and stored

- Machines and equipment are equipped with PLC controllers

- Internal communication of production with other functional and organizational units via e-post, typical telecommunication solutions

- Only local exchange of data and information in human-machine interaction (e.g., only at a given production site)

- Data from components that make up the production system are not generated and processed

- There is no automatic communication between machines and production equipment

- There is no internal integration in the communication of the production subsystem with other functional and organizational units of the enterprise

- There is no information and data exchange in the human-machine interaction 
Table A2. Criteria for evaluating the level of Digitalization of the Logistics System (DLS).

\begin{tabular}{|c|c|}
\hline Levels & Level/Activity Characteristics \\
\hline $\begin{array}{l}\text { Level 5: } \\
\text { full digitalization }\end{array}$ & $\begin{array}{l}\text { - Material, component, and finished product flows are automatically planned and } \\
\text { controlled } \\
\text { The logistics infrastructure used is able to communicate with other devices via } \\
\text { network services, Machine to Machine (M2M) software } \\
\text { - Internal communication within the company is fully interdepartmental, networked IT } \\
\text { solutions are fully utilized } \\
\text { - In the human-device interaction for data and information exchange, assistant software, } \\
\text { augmented reality, etc. are used } \\
\text { - Suppliers/customers are fully integrated, which allows automatic data exchange } \\
\text { between supply chain participants }\end{array}$ \\
\hline
\end{tabular}

- Collected data from logistics subsystems are analyzed and evaluated for material flow planning and control

- Owned logistics infrastructure has access to the Internet

Level 4:

interdepartmental digitalization

- Standardized internal communication (communication rules, data and information format) of logistics with other functional and organizational units

- In the human-device interaction for data and information exchange in the material flow, mobile devices are used

- Data and information are exchanged with suppliers/customers through solutions that provide automated data and information exchange

Level 3:

departmental digitalization

- Data from logistics systems are analyzed to monitor the flow of materials, components, or products

- The devices and/or other logistics infrastructure communicate via an industrial Ethernet network

- The internal communication (communication rules, data, and information format) on the logistics operations level is standardized

- Monitoring and control of logistic processes can be carried out centrally and locally

- With suppliers/customers, we use dedicated web portals with the possibility of data and information sharing

- The data generated during material flow are exclusively collected and stored.

- The logistics infrastructure is equipped with various types of controllers and sensors.

- Internal communication of logistics with other functional and organizational units

Level 2:

basic digitalization

$$
\text { through e-mail and traditional communication channels. }
$$

- In human-device interaction, data and information exchange are local (e.g., only for a given device, for a given logistic infrastructure).

- Data exchange with suppliers/customers through shared access to collected data, e.g., shared files, etc.
Level 1:

digitalization initiation
- $\quad$ Generated data during successive stages of material flow are not collected and processed

- There is no automatic communication between the machines and devices that make up the logistics infrastructure.

- There is no internal integration in the communication of the logistics subsystem with other functional and organizational units of the enterprise.

- There is no information and data exchange in the material flow.

- Communication with suppliers/customers takes place via e-mail and traditional communication 
Table A3. Criteria for assessing the maturity level of Industry 4.0 implementation of the Quality Management System (QMS).

\begin{tabular}{ll}
\hline Levels & Level/Activity Characteristics \\
\hline & - $\quad$ The organization manages processes all the time in an effort to continuously improve \\
them & Evidence of sustained improvement after an extended period of time, such as at least 3 \\
- & years \\
bevel 5: & Best practices and innovations are identified on an ongoing basis and communicated \\
best-in-class performance & throughout the enterprise
\end{tabular}

- The organization comprehensively measures and analyzes processes

Level 4:

focus on continuous improvement

- $\quad$ The system is able to predict trends in process and product quality

- Process capability is based on an understanding of the activities of the entire organization

- $\quad$ Evidence of sustained improvement after an extended period, such as at least one year
Level 3: stable, formal systems approach
- High repetition of activities performed

- The organization is based on a process approach

- $\quad$ Processes are well understood and described

- The organization measures process capability

- Occasional evidence of clear improvement or enhancement, although much evidence that the topic is not yet fully addressed
Level 2:

reactive approach
- Responding to issues as they arise

- $\quad$ Projects are managed based on previously mastered tasks that can be repeated

- Occasional reviews or evaluations that result in some refinement and improvement

- Inconsistent approach to quality management

- $\quad$ Processes are unpredictable, informal, and poorly controlled

Level 1:

no formal approach
- Implementation of individual activities is not clearly described or documented

- Activities are not performed in a repeatable manner

- $\quad$ Success depends on the individual capabilities of employees and managers

- $\quad$ Some good ideas may be present, but few have moved beyond the wishful thinking stage 
Table A4. Criteria for assessing the maturity level of the implementation of Industry 4.0 in the context of the changing competencies of employed engineers 4.0: The Maturity of Human Resources Management (HRM).

\begin{tabular}{|c|c|}
\hline Levels of Competence & Level/Activity Characteristics \\
\hline $\begin{array}{l}\text { Level 5: } \\
\text { skills for Industry } 4.0\end{array}$ & $\begin{array}{l}\text { Employed engineers possess: } \\
\text { - } \quad \text { Ability to manage machine-human interaction } \\
\text { - } \quad \text { Skill in managing networked distributed devices } \\
\text { - } \quad \text { Change management skills } \\
\text { - } \quad \text { Ability to manage a project team } \\
\text { - } \quad \text { Comprehensive engineering knowledge }\end{array}$ \\
\hline $\begin{array}{l}\text { Level 4: } \\
\text { technical skills }\end{array}$ & $\begin{array}{l}\text { Employed engineers, in addition to basic engineering, personal and social skills, have: } \\
\text { - } \quad \text { Ability to operate and maintain Industry } 4.0 \text { equipment } \\
\text { - } \quad \text { Knowledge of business, legal, and social issues } \\
\text { - } \quad \text { Knowledge of economic engineering issues } \\
\text { - } \quad \text { Knowledge of quality control issues, quality assurance using CSP } \\
\text { Knowledge of health and safety principles in the cooperation between man and } \\
\text { machine }\end{array}$ \\
\hline $\begin{array}{l}\text { Level 3: } \\
\text { social skills in the } \\
\text { organization }\end{array}$ & $\begin{array}{l}\text { Employed engineers, in addition to basic engineering and personnel skills, possess: } \\
\text { - } \quad \text { Teamwork skills } \\
\text { - } \quad \text { An understanding of customer needs } \\
\text { - } \quad \text { Ethical and professional responsibility } \\
\text { - } \quad \text { Knowledge of sustainability issues } \\
\text { - } \quad \text { Ability to plan and organize work using CSP } \\
\text { - } \quad \text { Problem-solving skills } \\
\text { - } \quad \text { Ideas and problem-spotting skills }\end{array}$ \\
\hline $\begin{array}{l}\text { Level 2: } \\
\text { personal skills }\end{array}$ & $\begin{array}{l}\text { Employed engineers, in addition to basic engineering skills, possess: } \\
\text { - } \quad \text { Communication skills } \\
\text { - } \quad \text { Openness to change } \\
\text { - } \quad \text { Professionalism } \\
\text { - } \quad \text { Abitiative and entrepreneurship } \\
\text { - } \quad \text { Solidarity } \\
\text { - }\end{array}$ \\
\hline $\begin{array}{l}\text { Level 1: } \\
\text { basic engineering skills }\end{array}$ & $\begin{array}{l}\text { Employed engineers have: } \\
\text { - } \quad \text { Engineering knowledge in the required area } \\
\text { - } \quad \text { Design skills } \\
\text { - } \quad \text { Manufacturing and construction skills } \\
\text { - } \quad \text { Kneration of equipment, use of technology } \\
\text { - } \quad \text { Critical thinking, analytical } \\
\text { - } \quad \text { Computer skills }\end{array}$ \\
\hline
\end{tabular}


Table A5. Criteria for assessing the level of maturity of Industry 4.0 implementation in the context of the Intensity of CSR activities (ICSR).

CSR Intensity Characteristics of CSR Intensity/Activities in the Area of CSR

Level 5:

pioneering

Level 4:

optimization

Level 3:

integration

Level 2:

inclusion/capacity

Level 1:

initiation
- Strategic, tactical, and operational objectives are aligned with local, regional, national, and international industry development goals.

- The enterprise controls its Industry 4.0 implementations in the context of environmental burdens.

- The enterprise controls the Industry 4.0 implementations of suppliers and sub-suppliers in the context of environmental burdens.

- The enterprise controls the activities of sales intermediaries in the context of environmental burdens.

- The organization is a leader in the development and promotion of CSR across the industry/has developed best practices in offsetting the impact of reducing human labor.

- It introduces collaborative robots.

- The organization collaborates with external parties to address environmental and social issues.

- A balanced scorecard measures the impact of a jointly developed product on the environment and the public/social sphere.

- The energy consumption of product users is measured.

- The organization meets CSR guidelines, thus contributing to the sustainability of the supply chain, network, region, and country.

- Implementation of social and environmental programs is measured and their effectiveness is proven.

- CSR information is available to customers.

- The social and environmental effects of cooperators' activities are measured, and CSR network programs are implemented.

- Supply chain operations strategies and tactical plans focus on addressing CSR issues

- The organization considers itself responsible when making decisions that it believes serve all stakeholders

- $\quad$ CSR information is made available to customers

- A social and environmental responsibility strategy is prepared

- Environmental compliance and product performance results are available for public review

- Investments and activities aimed at increasing social and environmental responsibility are not implemented 
Table A6. Criteria for assessing the level of maturity of Industry 4.0 implementation in the context of the Commitment to Product Innovation Development (CPID).

\begin{tabular}{|c|c|}
\hline Levels & Level/Activity Characteristics \\
\hline $\begin{array}{l}\text { Level 5: } \\
\text { pioneering }\end{array}$ & $\begin{array}{l}\text { - Use/exchange of resources between network companies as part of the innovation } \\
\text { development process } \\
\text { Knowledge of pro-innovation assets is generally available to all potential network } \\
\text { cooperators } \\
\text { - Joint innovation projects are supported by IT solutions, cloud work } \\
\text { Remote asset monitoring capabilities are integrated into the course of innovation } \\
\text { development processes in an open model-blockchain }\end{array}$ \\
\hline $\begin{array}{l}\text { Level 4: } \\
\text { optimization }\end{array}$ & $\begin{array}{l}\text { - The company has a complete picture of the pro-innovation assets of the cooperators } \\
\text { based on information, databases, and connectivity } \\
\text { - Asset information is based on real data that are monitored } \\
\text { - Performance and asset utilization is optimized based on agreements with other links in } \\
\text { the network (e.g., cluster animators) }\end{array}$ \\
\hline $\begin{array}{l}\text { Level 3: } \\
\text { integration }\end{array}$ & $\begin{array}{l}\text { - Audit of operations, performance, and product trend analysis is available to } \\
\text { collaborating organizations } \\
\text { - Inventory of supply chain partner assets is automated } \\
\text { - An application enabling modeling of the use of assets in key network cells is being } \\
\text { implemented }\end{array}$ \\
\hline $\begin{array}{l}\text { Level 2: } \\
\text { inclusion/capacity }\end{array}$ & $\begin{array}{l}\text { - The company completed a project to inventory and track pro-innovation assets for new } \\
\text { product development } \\
\text { - A database of assets of collaborators and networked organizations has been developed } \\
\text { - A strategy for the mobility of R\&D personnel in the network is being developed }\end{array}$ \\
\hline Level 1: initiation & $\begin{array}{l}\text { - R\&D personnel resource and competency management systems are assessed in terms } \\
\text { of their potential alignment with the vision of the network } \\
\text { - } \quad \text { Pro-innovative resources for the development of innovation are not monitored }\end{array}$ \\
\hline
\end{tabular}

Please send the table to the following address: ewa.stawiarska @polsl.pl (Thank you!)

Table A7. Table of respondent's answers.

\begin{tabular}{ccccccc}
\hline Areas & Table 1 & Table 2 & Table 3 & Tale 4 & Table 5 & Table 6 \\
\hline $\begin{array}{c}\text { Evaluation of } \\
\text { the level of }\end{array}$ & & & & & \\
involvement & & & & & \\
in Industry 4.0 & & & & & \\
from 1 to 5 & & & & & \\
\hline
\end{tabular}

\section{Additional questions}

1 Indicate the size of your company, please (underline the correct size)

\section{Large; Medium; Small; Micro}

2 Specify the class of the automotive part produced by the company (underline the correct class)

Engine; Powertrain; Chassis; Wheels/tires; Body; Electrical equipment; Technological components for building an automobile; Metal parts; Rubber parts; Rubber-metal parts; Plastic parts; Consumables; Vehicle safety equipment;

other what 
Table A8. Table of respondent's answers.

\begin{tabular}{ccccccc}
\hline Areas & Table 1 & Table 2 & Table 3 & Tale 4 & Table 5 & Table 6 \\
\hline $\begin{array}{c}\text { Evaluation of } \\
\text { the level of }\end{array}$ & & & & & \\
involvement & & & & \\
in Industry 4.0 & & & & & \\
from 1 to 5 & & & & & \\
\hline
\end{tabular}

\section{Additional questions}

1 Indicate the size of your company, please (underline the correct size)

Large; Medium; Small; Micro

2 Specify the class of the automotive part produced by the company (underline the correct class)

Engine; Powertrain; Chassis; Wheels/tires; Body; Electrical equipment; Technological components for building an automobile; Metal parts; Rubber parts; Rubber-metal parts; Plastic parts; Consumables; Vehicle safety equipment;

other what

\section{Appendix B Dictionary of Abbreviations}

\begin{tabular}{|c|}
\hline Dictionary of abbreviations \\
\hline ACATECH-Industry 4.0 implementation maturity model (proper name) \\
\hline APQP_Advanced Product Quality Planning \\
\hline BCG-Boston Consulting Group \\
\hline BSCI—Business Social Compliance Initiative \\
\hline CDIO_-Conceive-Design-Implement-Operate \\
\hline CEN TS 16555-European Standardization of Innovation Management \\
\hline CMMS_Computerized Maintenance Management Systems \\
\hline CPID—Commitment to Product Innovation Development \\
\hline CPS—Cyber-Physical Systems \\
\hline CSCMP_Council of Supply Chain Management Professionals \\
\hline CSR-Corporate Social Responsibility \\
\hline DGP_-Gross Domestic Product \\
\hline DLS-Digitalization of the Logistics System \\
\hline DPS—Digitalization of Production System \\
\hline DRIVES-Development and Research on Innovative Vocational Education Skills \\
\hline ERP-Enterprise Resource Planning \\
\hline e-SCM-Electronic Supply Chain Management \\
\hline ESCM-European Supply Chain Management \\
\hline FMEA-Failure Mode and Effects Analysis \\
\hline GSCM-Green Supply Chain Management \\
\hline HRM—Human Resources Management \\
\hline IAFT-International Automotive Task Force \\
\hline ICSR-Intensity of CSR Activities \\
\hline ICT-Information and Communications Technology \\
\hline
\end{tabular}




\begin{tabular}{l}
\hline IMPULS-Industry 4.0 implementation maturity model (proper name) \\
\hline IoT-Internet of Things \\
\hline ISO-International Organisation for Standardisation \\
\hline ISO/TS-International Organisation for Standardisation Technical Specification \\
\hline KPI-Key Performance Indicators \\
\hline MES-Manufacturing Execution Systems \\
\hline OEM-Original Equipment Manufacturer \\
\hline PDCA-Plan-Do-Check-Act \\
\hline QMS-Quality Management System \\
\hline R\&D-Research and Development \\
\hline RBT-Risk-Based Thinking \\
\hline SIMMI-Industry 4.0 implementation maturity model (proper name) \\
\hline WEF-World Economic Forum \\
\hline
\end{tabular}

\section{References}

1. Wilkesmann, M.; Wilkesmann, U. Industry 4.0-organizing routines or innovations? Vine J. Inf. Knowl. Manag. Syst. 2018, 48, 238-254. [CrossRef]

2. Prause, G.; Atari, S. On sustainable production networks for Industry 4.0. Int. J. Entrep. Sustain. 2017, 2, 421-431. [CrossRef]

3. Piccarozzi, M.; Aquilani, B.; Gatti, C. Industry 4.0 in management studies: A systematic literature review. Sustainability 2018, 10, 3821. [CrossRef]

4. Available online: https://www.researchgate.net/publication/322877322_When_titans_meet_-_Can_industry_40_revolutionise_ the_environmentally-sustainable_manufacturing_wave_The_role_of_critical_success_factors (accessed on 23 April 2021).

5. Frank, A.G.; Dalenogare, L.S.; Ayala, N.F. Industry 4.0 technologies: Implementation patterns in manufacturing companies. Int. J. Prod. Econ. 2019, 210, 15-26. [CrossRef]

6. Mittal, S.; Khan, M.A.; Romero, D.; Wuest, T. A critical review of smart manufacturing \& Industry 4.0 maturity models: Implications for small and medium-sized enterprises (SMEs). J. Manuf. Syst. 2018, 49, 194-214.

7. Breitschwerdt, D.; Cornet, A.; Michor, L.; Müller, N.; Salmon, L. Performance and Disruption-A Perspective on the Automotive Supplier Landscape and Major Technology Trends; Hg. v. McKinsey \& Company: Munich, Germany, 2018.

8. Benotsmane, R.; Dudás, L.; Kovács, G. Survey on New Trends of Robotic Tools in the Automotive Industry. In Vehicle and Automotive Engineering 3. VAE 2020; Jármai, K., Voith, K., Eds.; Springer: Berlin/Heidelberg, Germany, 2021. [CrossRef]

9. Parida, V.; Sjödin, D.; Reim, W. Reviewing literature on digitalization, business model innovation, and sustainable industry: Past achievements and future promises. Sustainability 2019, 11, 391. [CrossRef]

10. Wagire, A.A.; Joshi, R.; Rathore, A.P.S.; Jain, R. Development of maturity model for assessing the implementation of Industry 4.0: Learning from theory and practice. Prod. Plan. Control 2020, 1-20. [CrossRef]

11. Lin, D.; Lee, C.K.; Lau, H.; Yang, Y. Strategic response to Industry 4.0: An empirical investigation on the Chinese automotive industry. Ind. Manag. Data Syst. 2018, 118, 589-605. [CrossRef]

12. Qin, J.; Liu, Y.; Grosvenor, R. A categorical framework of manufacturing for industry 4.0 and beyond. Procedia Cirp 2016, 52, 173-178. [CrossRef]

13. Bibby, L.; Dehe, B. Defining and Assessing Industry 4.0 Maturity Levels-Case of the Defence Sector. Prod. Plan. Control 2018, 29, 1030-1043. [CrossRef]

14. Pacchini, A.P.T.; Lucato, W.C.; Facchini, F.; Mummolo, G. The degree of readiness for the Implementation of Industry 4.0. Comput. Ind. 2019, 113, 103-125. [CrossRef]

15. Rüßmann, M.; Lorenz, M.; Gerbert, P.; Waldner, M.; Justus, J.; Engel, P.; Harnisch, M. Industry 4.0: The Future of Productivity and Growth in Manufacturing Industries. Boston Consulting Group (BCG). 2015, pp. 1-14. Available online: https:/ /www.zvw.de/ media.media.72e472fb-1698-4a15-8858-344351c8902f.original.pdf (accessed on 25 April 2020).

16. Müller, J.M. Business model innovation in small-and medium-sized enterprises: Strategies for industry 4.0 providers and users. J. Manuf. Technol. Manag. 2019, 30, 1127-1142. [CrossRef]

17. Schneider, P. Managerial challenges of Industry 4.0: An empirically backed research agenda for a nascent field. Rev. Manag. Sci. 2018, 12, 803-848. [CrossRef]

18. Supply Chain Management Terms and Glossary. Available online: https://cscmp.org/CSCMP/Educate/SCM_Definitions_and_ Glossary_of_Terms.aspx (accessed on 25 April 2020).

19. Winkelhaus, S.; Grosse, E.H. Logistics 4.0: A systematic review towards a new logistics system. Int. J. Prod. Res. 2020, 58, 18-43. [CrossRef] 
20. Facchini, F.; Oleśków-Szłapka, J.; Ranieri, L.; Urbinati, A. A maturity model for logistics 4.0: An empirical analysis and a roadmap for future research. Sustainability 2020, 12, 86. [CrossRef]

21. Oleśków-Szłapka, J.; Stachowiak, A. The framework of logistics 4.0 maturity model. In Advances in Intelligent Systems and Computing; Springer: Wrocław, Poland, 2019.

22. Queiroz, M.M.; Pereira, S.C.F.; Telles, R.; Machado, M.C. Industry 4.0 and digital supply chain capabilities. Benchmarking Int. J. 2019. [CrossRef]

23. Boichuk, N. Identification and Evaluation of Industry 4.0 Solutions in the Automotive Industry-a Case Study. Sil. Univ. Technol. Sci. Pap. Organ. Manag. 2020, 147, 53-64.

24. Miśkiewicz, R.; Wolniak, R. Practical application of the Industry 4.0 concept in a steel company. Sustainability 2020, $12,5776$. [CrossRef]

25. Švingerová, M.; Melichar, M. Evaluation of process risks in industry 4.0 environment. In Proceedings of the Annals of DAAAM and the International DAAAM Symposium, Zadar, Croatia, 8-11 November 2017; pp. 1021-1029.

26. Wolniak, R. Quantitative relations between the implementation of industry management systems in European Union countries. Sil. Univ. Technol. Sci. Pap. Organ. Manag. 2020, 147, 33-44. [CrossRef]

27. Wolniak, R.; Saniuk, S.; Grabowska, S.; Gajdzik, B. Identification of energy efficiency trends in the context of the development of industry 4.0 using the Polish steel sector as an example. Energies 2020, 13, 2867. [CrossRef]

28. Trofimova, M.S.; Panov, A.Y. Technique for analysis of defects of products machine building according to IATF 16949:2016 standard requirements. J. Phys. Conf. Ser. 2020, 1210, 012145. [CrossRef]

29. Laurentiu-Aurel, M. Organizational process mappling for ISO/TS 16949:2009 certification of industrial quality management systems. Bull. Transilv. Univ. Bras. 2009, 51, 89-96.

30. Wierzbic, A.; Szewczyk, K. Ddigitalization of audit actions in the Industry 4.0 era. Inform. Ekon. 2019, 4, 74-87.

31. Ambrose, P. IATF 16949-2016 Plus ISO 9001-2015: Assessment Audit Guide and Checklist; CreateSpace: New York, NY, USA, 2017.

32. Benabdellah, A.C.; Benghabrit, A.; Bouhaddou, I.; Benghabrit, O. Design for relevance concurrent engineering approach: Integration of IATF 16949 requirements and design for X techniques. Res. Eng. Des. 2020, 31, 323-351. [CrossRef]

33. Reid, R.D. IATF 16949:2016's evolution. Qual. Prog. 2017, 50, 56-57.

34. Reid, R.D. Keys to IATF 16949:2016: Understanding important changes to the automotive QMS. Qual. Prog. 2017, 50, 48-50.

35. Chiarin, A.; Cherrafi, A. How ISO/TS 16949 certification can improve performance results through lean six sigma tools and principles: A case study from Italy. In Proceedings of the International Conference on Industrial Engineering and Operations Management, Rabat, Morocco, 11-13 April 2017; p. 782.

36. Gruszka, J.; Misztal, A. The new IATF 16949:2016 standard in the automotive supply chain. Res. Logist. Prod. 2017, 7, 311-318. [CrossRef]

37. Kasyanov, S.V. Technological preparation of production for product quality management according to IATF 16949:16 requirements. Iop Conf. Ser. Mater. Sci. Eng. 2020, 915, 012025. [CrossRef]

38. Laskurain-Iturbe, I.; Arana-Landín, G.; Heras-Saizarbitoria, I.; Boiral, O. How does IATF 16949 add value to ISO 9001? An empirical study. Total Qual. Manag. Bus. Excell. 2020. [CrossRef]

39. Rosak-Szyrocka, J. Automotive standard ISO/TS 16949 as a quality determinant. Prod. Eng. Arch. 2016, 10, 25-28. [CrossRef]

40. Rosak-Szyrocka, J.; Borkowski, S. ISO/TS 16949 system in quality aspect. Prod. Eng. Arch. 2014, 5, 22-25. [CrossRef]

41. Hys, K. ISO/TS 16949 analysis of the current trend. Zarzadzanie I Finans. 2015, 2, 37-41.

42. Loncea, E. Efficient evaluation of quality management system by optimum organization processes in the automotive industry in compliance with ISO/TS 16949:2009. Qual.-Access Success 2010, 11, 28-36.

43. Komarnicka, A.; Sąsiadek, M.; Nahirny, T. Wyzwania przemysłu motoryzacyjnego w świetle wprowadzania standardów IATF 16949:2016, [red.] R. Knosala. Przemyst a Zarzadzanie i Inżynieria Produkcji. Polskie Towarzystwo Zarzadzania Produkcja, Opole. Available online: http:/ /www.ptzp.org.pl/files/konferencje/kzz/artyk_pdf_2018/T2/2018_t2_251.pdf (accessed on 15 February 2021).

44. WEF 2020, The Future of Jobs Report. 20 October 2020. Available online: https://www.weforum.org/reports/the-future-of-jobsreport-2020 (accessed on 17 May 2020).

45. Larsen, C.; Rand, S.; Schmid, A.; Dean, A. (Eds.) Developing Skills in a Changing World of Work: Concepts, Measurement and Data Applied in Regional and Local Labour Market Monitoring Across Europe; Rainer Hampp Verlag: Augsburg/München, Germany, 2018.

46. 2018 Deloitte, 2018. 2018 Deloitte Skills Gap and Future of Work in Manufacturing Study. Available online: https: //www2.deloitte.com/content/dam/insights/us/articles/4736_2018-Deloitte-skills-gap-FoW-manufacturing/DI_2018 -Deloitte-skills-gap-FoW-manufacturing-study.pdf (accessed on 12 May 2020).

47. Störmer, E.; Patscha, C.; Prendergast, J.; Daheim, C.; Rhisiart, M.; Glover, P.; Beck, H. The Future of Work: Jobs and Skills in 2030. Evidence Report 84, UK Commission for Employment and Skills. 2014. Available online: https://www.gov.uk/government/ publications/jobs-and-skills-in-2030 (accessed on 16 May 2020).

48. Meyer, G.; Brunig, B.; Nyhuis, P. Employee competencies in manufacturing companies-an expert survey. J. Manag. Dev. 2015, 34, 1004-1018. [CrossRef]

49. Frey, C.B.; Osborne, M. The future of employment: How susceptible are jobs to computerisation? Technol. Forecast. Soc. Chang. 2016, 14, 254-280. [CrossRef] 
50. PwC. Will Robots Steal Our Jobs? An International Analysis of the Potential Long Term Impact of Automation. 2018 PricewaterhouseCoopers LLP. 2018. Available online: https://www.pwc.com/hu/hu/kiadvanyok/assets/pdf/impact_of_automation_on_ jobs.pdf (accessed on 9 April 2020).

51. Huber, W. Industrie 4.0 in der Automobilproduktion. In Ein Praxisbuch; Springer Vieweg: Wiesbaden, Germany, $2016 ;$ p. 16.

52. Longo, F.; Nicoletti, L.; Padovano, A. Smart operators in industry 4.0: A human-centered approach to enhance operators' capabilities and competencies within the new smart factory context. Comput. Ind. Eng. 2017, 113, 144-159. [CrossRef]

53. Hirsch-Kreinsen, H. Welche Auswirkungen hat die Zukunftsindustrie auf die Beschäftigten? RKW Mag. 2013, 4, 21-23.

54. Leslie, C. Engineering Competency Model. In Proceedings of the ASEE's 23rd Annual Conference \& Exposition, New Orleans, LA, USA, 26-29 June 2016; Available online: https:/ / www.asee.org/public/conferences/64/papers/16232/view (accessed on 12 January 2020).

55. Prifti, L.; Knigge, M.; Kienegger, H.; Krcmar, H. A competency model for “Industrie 4.0" Employees, Wirtschafts Informatyk 2017. pp. 46-60. Available online: www.wi2017.ch/images/wi2017-0262.pdf (accessed on 9 April 2020).

56. Popkova, E.G.; Zmiyak, K.V. Priorities of training of digital personnel for industry 4.0: Social competencies vs technical competencies. Horizon 2019, 27, 138-144. [CrossRef]

57. Nosalska, K.; Gracel, J. Kompetencje pracowników a kształtowanie dojrzałości cyfrowej przedsiębiorstw w kontekście Przemysłu 4.0. Zarzadzanie Zasobami Ludzkimi 2019, 3-4, 73-86.

58. Morgan, J. The Future of Work-Attract New Talent, Build Better Leaders, and Create a Competitive Organization; John Wiley \& Sons: Hoboken, NJ, USA, 2014.

59. Hermann, M.; Pentek, T.; Otto, B. Design Principles for Industrie 4.0 Scenarios. In Proceedings of the 201649 th Hawaii International Conference on System Sciences (HICSS), Koloa, HI, USA, 5-8 January 2016; pp. 3928-3937. [CrossRef]

60. Gracel, J.; Stoch, M.; Biegańska, A. Inżynierowie przemysłu 4.0 (nie)gotowi do zmian? In Astor Whitepaper; ASTOR: Kraków, Poland, 2017; pp. 33-56.

61. Gracel, J.; Makowiec, M. Kluczowe kompetencje menedżera w dobie czwartej rewolucji przemysłowej-Przemysłu 4.0. Acta Univ. Nicolai Copernic. Zarzadzanie 2017, 44, 105-129. [CrossRef]

62. Grzybowska, K.; Łupicka, A. Key competencies for Industry 4.0. Econ. Manag. Innov. 2017, 1, $250-253$.

63. Passow, H.; Passow, C. What competencies should undergraduate engineering programs emphasize? A systematic review. J. Eng. Educ. 2017, 106, 475-526. [CrossRef]

64. Hernandez-de-Menendez, M.; Morales-Menendez, R.; Escobar, C.A.; McGovern, M. Competencies for Industry 4.0. Int. J. Interact. Des. Manuf. 2020, 14, 1511-1524. [CrossRef]

65. Gehrke, L.; Kühn, A.T.; Rule, D.; Moore, P.; Bellmann, C.; Siemes, S.; Dawood, D.; Singh, L.; Kulik, J.; Standley, M. Industry 4.0-A Discussion of Qualifications and Skills in the Factory of the Future: A German and American Perspective; VDI The Association of German Engineers, ASME American Society of Mechanical Engineers: Düsseldorf, Germany, 2015.

66. Available online: https:/ / books.google.com.hk/books?id=MtU5BAAAQBAJ\&printsec=frontcover\#v=onepage\&q\&f=false $($ accessed on 11 August 2014).

67. Toffler, A. The Third Wave; William Collins Sons \& Co Ltd.: London, UK, 1980.

68. Smart Industry Polska 2019. Inżynierowie w Dobie Czwartej Rewolucji Przemysłowej. Raport z Badań. Warszawa, Poland, 2019. Available online: https://publikacje.siemens-info.com/ebook/554/raport-smart-industry-polska-2019 (accessed on 12 March 2020).

69. Ensser, M.; Gerhard, T. Digitales Deutschland? CEOs und Aufsichtsratsvorsitzende sagen, wo wir stehen und was uns jetzt nach vorne bringt, Egon Zehnder. 2016. Available online: https://www.egonzehnder.com/de/insight/nur-mut-vorwort-aus-derstudie-digitales-deutschland-ceos-und-aufsichtsratsvorsitzende-sagen-wo-wir-stehen-und-was-uns-jetzt-nach-vorne-bringt (accessed on 15 March 2020).

70. Cheng, W.-J.; Pien, L.-C.; Cheng, Y. Occupation-level automation probability is associated with psychosocial work conditions and workers' health: A multilevel study. Am. J. Ind. Med. 2021, 64, 108-117. [CrossRef]

71. Dumitrescu, A.; Lima, R.; Chattinnawat, W.; Savu, T. Industry 4.0 competencies' gap analysis. Int. Sci. J. 2019, 4, $153-156$.

72. Egon Zehnder, 2016. Global Board Diversity Analysis. Available online: https://www.egonzehnder.com/what-we-do/boardadvisory /insights / 2016-global-board-diversity-analysis (accessed on 12 May 2020).

73. Gino, F.; Staats, B. Dlaczego organizacje nie potrafia się uczyć? Harv. Bus. Rev. Pol. 2016, 161/162, 7-8.

74. Müller, J.M. Assessing the barriers to Industry 4.0 implementation from a workers' perspective. IFAC-PapersOnLine 2019, 52, 2189-2194. [CrossRef]

75. Stentoft, J.; Jensen, K.W.; Philipsen, K.; Haug, A. Drivers and barriers for Industry 4.0 readiness and practice: A SME perspective with empirical evidence. In Proceedings of the 52nd Hawaii International Conference on System Sciences, Grand Wailea, Maui, HI, USA, 8-11 January 2019; Volume 6, pp. 5155-5164.

76. World Economic Forum. In Proceedings of the World Economic Forum, Davos-Klosters, Switzerland, 23-26 January 2018.

77. Stock, T.; Seliger, G. Opportunities of sustainable manufacturing in industry 4.0. Procedia Cirp 2016, 40, 536-541. [CrossRef]

78. Machnik-Słomka, J. Smart specialization as a factor stimulating innovative development of water and wastewater economy. In Proceedings of the 2nd International Conference on Science and Technology Current Issues in Water Distribution and Treatment (CIWT 2017), Brenna, Poland, 31 May-2 June 2017; Zimoch, I., Ed.; EDP Sciences: Les Ulis, France, 2018; pp. $123-134$. 
79. Shrouf, F.; Ordieres, J.; Miragliotta, G. Smart factories in Industry 4.0: A review of the concept and of energy management approached in production based on the Internet of Things paradigm. In Proceedings of the 2014 IEEE International Conference on Industrial Engineering and Engineering Management 2014, Selangor Darul Ehsan, Malaysia, 9-12 December 2014 ; pp. 697-701.

80. Gabriel, M.; Pessl, E. Industry 4.0 and sustainability impacts: Critical discussion of sustainability aspects with a special focus on future of work and ecological consequences. Ann. Fac. Eng. Hunedoara 2016, 14, 131.

81. Sarkis, J.; Zhu, Q. Environmental sustainability and production: Taking the road less travelled. Int. J. Prod. Res. 2018, 56, 743-759. [CrossRef]

82. Miśkiewicz, R. Industry 4.0 in Poland-Selected Aspects of Its Implementation. Zeszyty Naukowe Politechniki Ślaskiej 2019, 136, 403-413.

83. Hąbek, P.; Villahoz, J.J.L. Socially Responsible Supplier Development. Pract. Automot. Ind. MAPE 2020, 3, 707-719.

84. Müller, J.M.; Kiel, D.; Voigt, K.I. What drives the implementation of Industry 4.0? The role of opportunities and challenges in the context of sustainability. Sustainability 2018, 10, 247. [CrossRef]

85. Varela, L.; Araújo, A.; Ávila, P.; Castro, H.; Putnik, G. Evaluation of the relation between lean manufacturing, industry 4.0, and sustainability. Sustainability 2019, 11, 1439. [CrossRef]

86. Tseng, M.L.; Tan, R.R.; Chiu, A.S.; Chien, C.F.; Kuo, T.C. Circular economy meets industry 4.0: Can big data drive industrial symbiosis? Resour. Conserv. Recycl. 2018, 131, 146-147. [CrossRef]

87. Beltrami, M.; Orzes, G. Industry 4.0 and sustainability: A systematic literature review. Decision Sciences in a Connected World 2019. In Proceedings of the 10th Annual EDSI Conference, Nottingham, UK, 2-5 June 2019.

88. de Sousa Jabbour, A.B.L.; Jabbour, C.J.C.; Foropon, C.; Godinho Filho, M. When titans meet-Can industry 4.0 revolutionise the environmentally-sustainable manufacturing wave? The role of critical success factors. Technol. Forecast. Soc. Chang. 2018, 132, 18-25. [CrossRef]

89. Dalenogare, L.S.; Benitez, G.B.; Ayala, N.F.; Frank, A.G. The expected contribution of Industry 4.0 technologies for industrial performance. Int. J. Prod. Econ. 2018, 204, 383-394. [CrossRef]

90. Witkowski, K. Internet of things, big data, industry 4.0-innovative solutions in logistics and supply chains management. Procedia Eng. 2017, 182, 763-769. [CrossRef]

91. Kruger, S.; Steyn, A.A. A conceptual model of entrepreneurial competencies needed to utilise technologies of Industry 4.0. Technol. Soc. 2021, 64, 101454. [CrossRef]

92. Simona Šarotar, Ž.; Zlatko, N.; Matjaž, M.; Živa, V.Č. Key Performance Indicators and Industry 4.0-A Socially Responsible Perspective. Sciendo 2020, 66, 22-34.

93. Frank, A.G.; Mendes, G.H.; Ayala, N.F.; Ghezzi, A. Servitization and Industry 4.0 convergence in the digital transformation of product firms: A business model innovation perspective. Technol. Forecast. Soc. Chang. 2019, 141, 341-351. [CrossRef]

94. Bai, C.; Dallasega, P.; Orzes, G.; Sarkis, J. Industry 4.0 technologies assessment: A sustainability perspective. Int. J. Prod. Econ. 2020. [CrossRef]

95. Kamble, S.S.; Gunasekaran, A.; Gawankar, S.A. Sustainable Industry 4.0 framework: A systematic literature review identifying the current trends and future perspectives. Process Saf. Environ. Prot. 2018, 117, 408-425. [CrossRef]

96. Dremel, C.; Wulf, J.; Maier, A.; Brenner, W. Understanding the value and organizational implications of big data analytics: The case of AUDI AG. J. Inf. Technol. Teach. Cases 2018, 8, 126-138. [CrossRef]

97. Kanwal, M.; Khanam, F.; Nasreen, S.; Hameed, S. Impact of corporate social responsibility on the firm's financial performance. Bus. Manag. 2013, 14, 67-74.

98. Naderi, M.; Ares, E.; Peláez, G.; Prieto, D.; Araújo, M. Sustainable Operations Management for Industry 4.0 and its Social Return. ScienceDirect 2019, 52-53, 457-461. [CrossRef]

99. Carpejani, P.; Santor Bonfim, B.M.; Pierin, R. The Use of Digital Transformation as a Sustainable Mechanism: An Automotive Industry Case. In International Business, Trade and Institutional Sustainability. World Sustainability Series; Leal Filho, W., Borges de Brito, P., Frankenberger, F., Eds.; Springer: Cham, Germany, 2020. [CrossRef]

100. Cunha, J.; Ferreira, P.; Araújo, M.; Ares Goméz, E. Social Return of R\&D investments in Manufacturing Sector: Some Insights from an Exploratory Case Study. AIP Conf. Proc. 2012, 1431, 43.

101. Fernández, A.; Cunha, J.; Ares Goméz, E. Social impact on project assessment: An integrated methodology for the assessment of investment projects in Research and Development (R\&D) at a society level. In Proceedings of the International Conference on Project Economic Evaluation, Guimarăes, Portugal, 28-29 April 2011.

102. Fernández, A.; Cunha, J.; Ferreira, P.; Araújo, M.; Ares, E. Research and Development Project Assessment and Social Impact Production. Production 2015, 25, 725-738. [CrossRef]

103. Naderi, M.; Ares, E.; Peláez, G.; Prieto, D.; Fernández, A.; Ferreira, L.P. The sustainable evaluation of manufacturing systems based on simulation using an economic index function: A case study. Procedia Manuf. 2017, 13, 1043-1050. [CrossRef]

104. Luthra, S.; Mangla, S.K. Evaluating challenges to Industry 4.0 initiatives for supply chain sustainability in emerging economies. Process Saf. Environ. Prot. 2018, 117, 168-179. [CrossRef]

105. Stawiarska, E.; Sobczak, P. The impact of intelligent transportation system implementations on the sustainable growth of passenger transport in EU regions. Sustainability 2018, 10, 1318. [CrossRef] 
106. Jabbour, C.J.C.; de Sousa, A.B.L.; Sarkis, J.; Godinho Filho, M. Unlocking the circular economy through new business models based on large-scale data: An integrative framework and research agenda. Technol. Forecast. Soc. Chang. 2019, 144, 546-552. [CrossRef]

107. Mathivathanan, D.; Kannan, D.; Haq, A.N. Sustainable supply chain management practices in Indian automotive industry: A multi-stakeholder view. Resour. Conserv. Recycl. 2018, 128, 284-305. [CrossRef]

108. Tu, M.; Lim, M.; Yang, M.F. IoT-based production logistics and supply chain system-Part 2: IoT-based cyber-physical system: A framework and evaluation. Ind. Manag. Data Syst. 2018, 118, 96-125. [CrossRef]

109. Handayani, R.; Wahyudi, S.; Suharnomo, S. The effects of corporate social responsibility on manufacturing industry performance: The mediating role of social collaboration and green innovation. Bus. Theory Pract. 2017, 18, 152-159. [CrossRef]

110. Armengaud, E.; Sams, C.; von Falck, G.; List, G.; Kreiner, C.; Riel, A. Industry 4.0 as Digitalization over the Entire Product Lifecycle: Opportunities in the Automotive Domain. In Systems, Software and Services Process Improvement. EuroSPI 2017; Stolfa, J., Stolfa, S., O'Connor, R., Messnarz, R., Eds.; Communications in Computer and Information Science; Springer: Cham, Swizerland, 2017; Volume 748. [CrossRef]

111. Bolton, A.; Goosen, L.; Kritzinger, E. Security Aspects of an Empirical Study into the Impir of Digital Transformation via Unified Communication and Collaboration Technologies on the Productivity and Innovation of a Global Automotive Enterprise Enterprise. In Information and Cyber Security. ISSA 2019. Communications in Computer and Information Science, tom 1166; Venter, H., Loock, M., Coetzee, M., Eloff, M., Eloff, J., Eds.; Springer: Cham, Swizerland, 2020. [CrossRef]

112. Brem, A.; Voigt, K.-I. Integration of market pull and technology push in the corporate front end and innovation managementInsights from the German software industry. Technovation 2009, 29, 351-367. [CrossRef]

113. Brzóska, J. Innowacje Jako Czynnik Dynamizujacy Modele Biznesowe; Silesian Uniwersity of Technology: Gliwice, Poland, $2014 ;$ p. 34.

114. Koen, P.; Ajamian., G.; Burkart, R.; Clamen, A.; Davidson, J.; D’Amore, R.; Elkins, C.; Herald, K.; Incorvia, M.; Johnson, A.; et al. Providing Clarity and Common Language to the "Fuzzy Front End". Res. Technol. Manag. 2001, 44, 46-55. [CrossRef]

115. Poznańska, K.; Kraj, K.M. Badania i Rozwój w Korporacjach Transnarodowych Organizacja i Umiędzynarodowienie; PWN: Warszawa, Poland, 2015; pp. 129-148.

116. Stawiarska, E. Modele Zarzadzania Innowacjami w Łańcuchach i Sieciach Dostaw Międzynarodowych Koncernów Motoryzacyjnych; CeDeWu: Warszwa, Poland, 2019; p. 56.

117. Chesbrough, H.; Crowther, A.K. Beyond high tech: Early adopters of open innovation in other industries. $R$ D Manag. 2006, 36, 229-236. [CrossRef]

118. Günay, G.; Aldemir, G.; Çebi, F. Innovation Efficiency in Automotive Industry: The Case of Turkey. In Digital Conversion on the Way to Industry 4.0. ISPR 2020. Lecture Notes in Mechanical Engineering; Durakbasa, N.M., Gençyllmaz, M.G., Eds.; Springer: Cham, Swizerland, 2021. [CrossRef]

119. Reischauer, G. Industry 4.0 as policy-driven discourse to institutionalize innovation systems in manufacturing. Technol. Forecast. Soc. Chang. 2018, 132, 26-33. [CrossRef]

120. Nellippallil, A.B.; Ming, Z.; Allen, J.K. Cloud-Based Materials and Product Realization—Fostering ICME Via Industry 4.0. Integr. Mater. Manuf. Innov. 2019, 107-121. [CrossRef]

121. Oliveira, J.; Nunes, M.; Afonso, P. New Product Development in the Context of Industry 4.0: Insights from the Automotive Components Industry. In Industrial Engineering and Operations Management II. IJCIEOM 2018. Springer Proceedings in Mathematics E Statistics; Reis, J., Pinelas, S., Melão, N., Eds.; Springer: Cham, Swizerland, 2020. [CrossRef]

122. Nascimento, J.; Cessa, A. Use of Industry 4.0 Concepts to Use the "Voice of the Product" in the Product Development Process in the Automotive Industry. In Product Lifecycle Management (Volume 4): The Case Studies. Decision Engineering; Stark, J., Ed.; Springer: Cham, Swizerland, 2019.

123. Ruggero, S.M.; dos Santos, N.A.; Sacomano, J.B.; Estender, A.C.; da Silva, M.T. Industry 4.0: Maturity of Automotive Companies in Brazil for the Digitization of Processes. In Advances in Production Management Systems. The Path to Digital Transformation and Innovation of Production Management Systems. APMS 2020. IFIP Advances in Information and Communication Technology; Lalic, B., Majstorovic, V., Marjanovic, U., von Cieminski, G., Romero, D., Eds.; Springer: Cham, Swizerland, 2019; Volume 591. [CrossRef]

124. Chandriah, K.K.; Raghavendra, N.V. Architectural Framework for Industry 4.0 Compliance Supply Chain System for Automotive Industry. In Cybernetics and Automation Control Theory Methods in Intelligent Algorithms. CSOC 2019. Advances in Intelligent Systems and Computing; Silhavy, R., Ed.; Springer: Cham, Swizerland, 2019; Volume 986. [CrossRef]

125. Metallo, C.; Agrifoglio, R.; Schiavone, F.; Mueller, J. Understanding business model in the Internet of Things industry. Technol. Forecast. Soc. Chang. 2018, 136, 298-306. [CrossRef]

126. Fraga-Lamas, P.; Fernández-Caramés, T.M. A Review on Blockchain Technologies for an Advanced and Cyber-Resilient Automotive Industry. IEEE Access 2019, 7, 17578-17598. [CrossRef]

127. Sanz, E.; Blesa, J.; Puig, V. BiDrac Industry 4.0 framework: Application to an Automotive Paint Shop Process. IEEE Software 2021, $38,7-14$.

128. Ortega, V.; Bouchmal, F.; Monserrat, J.F. Trusted 5G vehicular networks: Blockchains and content-centric networking. IEEE Veh. Technol. Mag. 2018, 13, 121-127. [CrossRef]

129. Wang, M.; Duan, M.; Zhu, J. Research on the security criteria of hash functions in the blockchain. In Proceedings of the 2nd ACM Workshop Blockchains, Cryptocurrencies, Contracts (BCC), Incheon, Korea, 4-8 June 2018; pp. 47-55. 
130. Gatteschi, V.; Lamberti, F.; Demartini, C.; Pranteda, C.; Santamaría, V. Blockchain and smart contracts for insurance: Is the technology mature enough? Future Internet 2018, 10, 20. [CrossRef]

131. Riasanov, T.; Jäntgen, L.; Hermes, S. Klastry podstawowe, splecione i specyficzne dla ekosystemu w ekosystemach platform: Analiza podobieństw w cyfrowej transformacji branży motoryzacyjnej, blockchain, finansowej, ubezpieczeniowej i IIoT. Rynki Elektron. 2020. [CrossRef]

132. Hellingrath, B.; Lechtenberg, S. Zastosowania sztucznej inteligencji w zarządzaniu łańcuchem dostaw i logistyce: Focusing onto Recognition for Supply Chain Execution. W. In The Art of Structural; Bergener, K., Räckers, M., Stein, A., Eds.; Springer: Cham, Swizerland, 2019. [CrossRef]

133. Matusek, M. Supply chain of product-service solutions-case study. Zesz. Nauk. Politech. ŚląskiejOrgan. I Zarządzanie 2017, 101, 136-327.

134. Tarhan, A.; Turetken, O.; Reijers, H.A. Business process maturity models: A systematic literature review. Inf. Soft. Technol. 2016, 75, 122-134. [CrossRef]

135. Crosby, P. Quality Is Free; Mc-Graw Hill: New York, NY, USA, 1979.

136. Kosieradzka, A.; Smagowicz, J. Model dojrzałości organizacji w obszarze publicznego zarządzania kryzysowego. In Zeszyty Naukowe. Organizacja i Zarządzanie; Politechnika Śląska: Gliwice, Poland, 2018; Volume 128, pp. 217-230.

137. Mettler, T. Maturity assessment models: A design science research approach. Int. J. Soc. Syst. Sci. 2011, 3, 81-98. [CrossRef]

138. Leyh, C.; Schäffer, T.; Ble, K.; Forstenhäusler, S. SIMMI 4.0-A Maturity Model for Classifying the Enterprise-wide IT and Software Landscape Focusing on Industry 4.0. In Proceedings of the Federated Conference on Computer Science and Information Systems, Gdansk, Poland, 11-14 September 2016; Volume 1297-1302.

139. Schumacher, A.; Erol, S.; Sihn, W. A maturity model for assessing Industry 4.0 readiness and maturity of manufacturing enterprises. Procedia Cirp 2016, 52, 161-166. [CrossRef]

140. Schuh, G.; Anderl, R.; Gausemeier, J.; Hompel, M. Industrie 4.0 Maturity Index Managing the Digital Transformation of Companies; Acatech Study National Academy of Science and Engineering: Munich, Germany, 2017.

141. Lichtblau, K.; Stich, V.; Bertenrath, R.; Blum, M.; Bleider, M.; Millack, A.; Schmitt, K.; Schmitz, E.; Schröter, M. IMPULS-Industrie 4.0- Readiness; Impuls-Stiftung des VDM: Aachen-Köln, Germany, 2015.

142. Azevedo, A.; Santiago, S.B. Design of an Assessment Industry 4.0 Maturity Model: An application to manufacturing company. In Proceedings of the International Conference on Industrial Engineering and Operations Management, Toronto, ON, Canada, 23-25 October 2019.

143. Researchgate. Available online: https://www.researchgate.net/publication/331726191_Roadmapping_towards_industrial_ digitalization_based_on_an_Industry_40_maturity_model_for_manufacturing_enterprises (accessed on 25 July 2018).

144. Stawiarska, E.; Szwajca, D.; Matusek, M.; Wolniak, R. Wdrażanie Rozwiąań Przemystu 4.0; CeDeWu: Warszawa, Poland, 2021; pp. 208-209.

145. Porter, M. Przewaga Konkurencyjna; Wydawnictwo Helion: Gliwice, Poland, 2006.

146. Llopis-Albert, C.; Rubio, F.; Valero, F. Impact of digital transformation on the automotive industry. Technol. Forecast. Soc. Chang. 2021, 162, 120343. [CrossRef]

147. Lüthje, B. Going digital, going green: Changing production networks in the automotive industry in China. Int. J. Automot. Technol. Manag. 2021, 21, 121-136. [CrossRef]

148. Bulut Ibrahim, S.; Ilhan, H. Cloud-based architecture development to share vehicle and traffic information for industry 4.0. Lecture Notes Netw. Syst. 2021, 152, 41-54.

149. Erol, A.; Sihn, S.W. A maturity model for assessing Industry 4.0 readiness and maturity of manufacturing enterprises. In Proceedings of the Sixth International Conference on Changeable, Agile, Reconfigurable and Virtual, Bath, UK, 4-6 September 2016.

150. Available online: http:/ / ieomsociety.org/toronto2019/papers/59.pdf (accessed on 25 October 2019).

151. Wang, L.; Törngren, M.; Onori, M. Current status and advancement of cyber-physical systems in manufacturing. J. Manuf. Syst. 2016, 37, 517-527. [CrossRef]

152. BPC Guide. 2019. Available online: https:/ /bpc-guide.pl/nowe-wdrozenie-d365-oraz-trendy-w-systemach-erp-na-2019-rok/ (accessed on 15 February 2021).

153. Müller, J.; Voigt, K.I. Industry 4.0—integration strategies for small and medium-sized enterprises. In Proceedings of the 26th International Association for Management of Technology (IAMOT) Conference 2017, Vienna, Austria, $14-18$ May 2017.

154. Davies, R.; Coole, T.; Smith, A. Review of socio-technical considerations to ensure successful implementation of Industry 4.0. Procedia Manuf. 2017, 11, 1288-1295. [CrossRef]

155. Sony, M. Pros and cons of implementing Industry 4.0 for the organizations: A review and synthesis of evidence. Prod. Manuf. Res. 2020, 8, 244-272. [CrossRef]

156. Burmeister, C.; Luettgens, D.; Piller, F.T. Business Model Innovation for Industrie 4.0: Why the "Industrial Internet" Mandates a New Perspective on Innovation. Die Unternehmung. Swiss J. Bus. Res. Pract. 2015, 70, 124-152. [CrossRef]

157. Hajoary, P.K. Industry 4.0 Maturity and Readiness Models: A Systematic Literature Review and Future Framework. Int. J. Innov. Technol. Manag. 2021, 2030005. [CrossRef]

158. Hajoary, P.K.; Akhilesh, K.B. Conceptual Framework to Assess the Maturity and Readiness towards Industry 4.0. In Lecture Notes in Mechanical Engineering; Springer: Munich, Germany, 2021; pp. 13-23. 
159. Dikhanbayeva, D.; Shaikholla, S.; Suleiman, Z.; Turkyilmaz, A. Assessment of industry 4.0 maturity models by design principles. Sustainability 2021, 12, 9927.

160. Ortt, R.; Stolwijk, C.; Punter, M. Implementing Industry 4.0: Assessing the current state. J. Manuf. Technol. Manag. 2020, 31, 825-836. [CrossRef]

161. Ramos, L.; Loures, E.; Deschamps, F.; Venâncio, A. Systems evaluation methodology to attend the digital projects requirements for industry 4.0. Int. J. Comput. Integr. Manuf. 2020, 33, 398-410. [CrossRef]

162. Neves, F.D.O.; Salgado, E.G.; Beijo, L.A.; Lira, J.M.S.; Ribeiro, L.H.M.D.S. Analysis of the quality management system for automotive industry- ISO/TS 16949 in the world. Total Qual. Manag. Bus. Excell. 2021, 32, 153-176.

163. Şener, U.; Gökalp, E.; Eren, E. Towards a maturity model for industry 4.0: A systematic literature review and a model proposal. In Industry 4.0 from the MIS PerspectiveChapter; Peterlang: Berlin, Germany, 2018; pp. 291-303.

164. Gökalp, E.; Şener, U.; Eren, P.E. Development of an Assessment Model for Industry 4.0: Industry 4.0-MM. In Proceedings of the International Conference on Software Process Improvement and Capability Determination (SPICE), Palma de Mallorca, Spain, 4-5 October 2017; pp. 128-142.

165. Amaral, A.; Peças, P. SMEs and Industry 4.0: Two case studies of digitalization for a smoother integration. Comput. Ind. 2021, 125, 103333. [CrossRef]

166. Haiss, P.; Mahlberg, B.; Michlits, D. Industry 4.0-the future of Austrian jobs. Empirica 2021, 48, 5-36. [CrossRef]

167. Khan, N.; Khan, S.; Tan, B.C.; Loon, C.H. Driving Digital Competency Model towards IR 4.0 in Malaysia. J. Phys. Conf. Ser. 2021, 1793, 012049. [CrossRef]

168. Balog, M.M.; Demidova, S.E. Human Capital Development in the Context of the Fourth Industrial Revolution. IOP Conf. Ser. Earth Environ. Sci. 2021, 666, 062120. [CrossRef]

169. Chauhan, C.; Singh, A.; Luthra, S. Barriers to industry 4.0 adoption and its performance implications: An empirical investigation of emerging economy. J. Clean. Product. 2021, 285, 124809. [CrossRef]

170. MotoBarometr 2019. Nastroje w Automotive. Available online: https:/ / exactsystems.pl/_get/mb/MotoBarometr_Raport2019. pdf (accessed on 12 March 2020).

171. Ras, E.; Wild, F.; Stahl, C.; Baudet, A. Bridging the Skills Gap of Workers in Industry 4.0 by Human Performance Augmentation Tools: Challenges and Roadmap. In Proceedings of the 10th International Conference on Pervasive Technologies Related to Assistive Environments, New York, NY, USA, 21-23 June 2017; pp. 428-432.

172. Coşkun, S.; Kayıkc1, Y.; Gençay, E. Adapting engineering education to Industry 4.0 vision. Technologies 2019, 7, 10. [CrossRef]

173. Panasiuk, J.; Kaczmarek, W. Zapewnienie ciagłości edukacji technicznej w kontekście wymagań Przemysłu 4.0. Napędy I Sterow. 2018, 6, 80-85.

174. Díaz, M.; Flores, B. Competencies to adopt Industry 4.0 for operations management personnel at automotive parts suppliers in Nuevo Leon. In Proceedings of the International Conference on Industrial Engineering and Operations Management, Bogota, Colombia, 25-26 October 2017; pp. 736-747.

175. Erola, S.; Jägera, A.; Holda, P.; Otta, K.; Sihna, W. Tangible Industry 4.0: A scenario-based approach to learning for the future of production. Procedia Cirp 2016, 54, 13-18. [CrossRef]

176. Mourtzis, D.; Vlachou, E.; Dimitrakopoulos, G.; Zogopoulos, V. Cyber-physical systems and education 4.0: The teaching factory 4.0 concept. Procedia Manuf. 2018, 23, 129-134. [CrossRef]

177. DRIVES. 2018. Available online: https:/ /www.project-drives.eu/en/home (accessed on 15 May 2020).

178. Hecklau, F.; Galeitzke, M.; Flachs, S.; Kohl, H. Holistic approach for human resource management in Industry 4.0. Procedia Cirp 2016, 54, 1-6. [CrossRef]

179. Benesova, A.; Tupa, J. Requirements for education and qualification of people in Industry 4.0. Procedia Manuf. 2017, 11, $2195-2202$. [CrossRef]

180. Wang, G.; Gunasekaran, A.; Ngai, E.W.; Papadopoulos, T. Big data analytics in logistics and supply chain management: Certain investigations for research and applications. Int. J. Prod. Econ. 2016, 176, 98-110. [CrossRef]

181. Bhandari, D.; Singh, R.K.; Garg, S.K. Prioritisation and evaluation of barriers intensity for implementation of cleaner technologies: Framework for sustainable production. Resour. Conserv. Recycl. 2019, 146, 156-167. [CrossRef]

182. Birkel, H.S.; Veile, J.W.; Müller, J.M.; Hartmann, E.; Voigt, K.-I. Development of a risk framework for Industry 4.0 in the context of sustainability for established manufacturers. Sustainability 2019, 11, 384. [CrossRef]

183. Benitez, G.B.; Ayala, N.F.; Frank, A.G. Industry 4.0 innovation ecosystems: An evolutionary perspective on value cocreation. Int. J. Prod. Econ. 2020, in press. [CrossRef] 